\title{
PENGARUH PROFITABILITAS, LEVERAGE, GROWTH, SIZE TERHADAP HARGA SAHAM \\ DENGAN PENGUNGKAPAN TANGGUNG JAWAB SOSIAL SEBAGAI VARIABEL \\ INTERVENING PADA PERUSAHAAN YANG TERDAFTAR \\ DI BURSA EFEK INDONESIA
}

\author{
Ardi Manuel Lomboan \\ Jullie J. Sondakh \\ Winston Pontoh \\ (e-mail : ardimanuellomboan@yahoo.com)
}

\begin{abstract}
The more rapidly business development currently rises tight competition among corporate companies, either national or international. Company does not longer become entity that only focuses to itself thus separate from sosial environment, but become the part of the environment so there is an interaction that arises, caused by the positive response from surrounded environment to its existence.

This research purpose is to find out the influence of Profitability, leverage, growth, and size to stock price with company social responsibility disclosure as intervening variable at listed companies in BEI at periode of 2010 - 2012.

Its population is companies that are listed in BEI at 2010 - 2012 periode, as much as 525 companies. By using judgement sampling method, it is obtained 55 companies as sample.

The used analysis method is path analysis, while research data processing uses computer program IBM SPSS Statistic 22.

From testing calculation, it is found that the testing of profitability, leverage, growth, size and company social responsibility disclosure simultaneously have significant influence to stock price of listed companies in BEI. Partially, Profitability does not significantly influence company social responsibility disclosure; Leverage significantly influences to company social responsibility disclosure; Growth does not significantly influence company social responsibility disclosure; Size significantly influence company social responsibility disclosure; Profitabiliy significantly influence stock price; Leverage significantly influence stock price; Growth does not significantly influence stock price; Size significantly influences stock price; company social responsibility disclosure does not significantly influence stock price. Profitability does not significantly influence stock price through company social responsibility disclosure; Leverage significantly influences stock price through company social responsibility disclosure; Growth significantly influence stock price through company social responsibility disclosure; Size does not significantly influence stock price through company social responsibility disclosure
\end{abstract}

Keywords: Profitability, Leverage, Growth, Size, Company Social Responsibility Disclosure, and Stock Price.

\section{PENDAHULUAN}

\section{Latar Belakang Masalah}

Perekonomian dunia saat ini yang semakin berkembang serta didukung oleh kemajuan teknologi yang begitu pesat, melahirkan banyak sekali perusahaan - perusahaan besar berskala nasional maupun internasional. Penerbitan laporan keuangan maupun non keuangan merupakan media informasi yang penting bagi para stakeholders dalam rangka melakukan evaluasi kinerja maupun aktivitas perusahaan. Menurut Undang -undang Pasar Modal No. 8 tahun 1995 pasal 1: Informasi atau fakta material adalah informasi atau fakta penting dan relevan mengenai peristiwa, kejadian atau fakta yang dapat mempengaruhi harga efek pada Bursa Efek, dan atau keputusan pemodal, calon pemodal atau pihak lain yang berkepentingan atas informasi atau fakta tersebut.

Dalam pengambilan keputusan investasi, seringkali investor juga melakukan penilaian melalui: profitabilitas, leverage, growth, dan size perusahaan. Sujoko dan Soebiantoro (2007) mengemukakan bahwa dengan profitabilitas yang tinggi, investor akan merespon positif sinyal tersebut sehingga nilai perusahaan meningkat. Leverage yang diukur dengan Debt to Equity ratio (DER) memiliki pengaruh signifikan terhadap harga saham (Pasaribu, 2008) (Dewi dan Suaryana, 2013). Kusumajaya (2011) mengemukakan bahwa tingkat pertumbuhan perusahaan yang diukur dengan pertumbuhan penjualan 
mempengaruhi nilai perusahaan atau harga saham perusahaan sebab pertumbuhan perusahaan menjadi tanda perkembangan perusahaan yang baik yang berdampak respon positif dari investor. Ukuran perusahaan (size) dianggap mampu mempengaruhi nilai perusahaan, nilai suatu perusahaan dapat dilihat dari harga sahamnya. Semakin besar ukuran atau skala perusahaan maka akan semakin mudah pula perusahaan memperoleh sumber pendanaan baik yang bersifat internal maupun eksternal.

Perusahaan yang semakin berkembang ini pun seringkali menimbulkan kesenjangan sosial dan kerusakan lingkungan akibat dari aktivitas yang tidak terkendali dalam rangka meningkatkan laba perusahaan. Dunia bisnis saat ini menuntut perusahaan untuk mampu menyeimbangkan pencapaian kinerja ekonomi (profit), kinerja sosial (people) dan kinerja lingkungan (planet) atau disebut triple bottom line - perforance. Sejalan dengan perkembangan tersebut, Undang - Undang No. 40 tahun 2007 tentang Perseroan Terbatas diterbitkan dan mewajibkan perseroan yang bidang usahanya di bidang atau terkait dengan bidang sumber daya alam untuk melaksanakan tanggung jawab sosial dan lingkungan. Dalam Undang - Undang Penanaman Modal No. 25 tahun 2007 pasal 15 bagian (b), pasal 17, dan pasal 34 yang mengatur bahwa setiap penanaman modal diwajibkan untuk ikut serta dalam tanggung jawab sosial. Ikatan Akutan Indonesia (IAI) dalam Pernyataan Standar Akutansi Keuangan (PSAK) Nomor 1 (revisi 2015) paragraf sembilan secara implisit juga menyarankan untuk mengungkapkan tanggung jawab akan masalah. Pada tanggal 1 November 2010 lalu sebuah "standar" mengenai bagaimana tanggung jawab sosial seharusnya dilaksanakan diluncurkan. Dokumen ISO 26000:2010 Guidance on Social Responsibility itu utamanya berisikan definisi, prinsip, subjek inti dan petunjuk bagaimana prinsip dan subjek inti tersebut ditegakkan di dalam organisasi.

Berdasarkan pembahasan sebelumnya maka penulis mengajukan tesis dengan judul: Pengaruh

Profitabilitas, Leverage, Growth, dan Size Terhadap Harga Saham dengan Pengungkapan Tanggung Jawab Sosial Perusahaan sebagai Variabel Intervening pada Perusahaan yang terdaftar di BEI. Berdasarkan latar belakang yang dikemukakan maka masalah yang timbul adalah: Apakah profitabilitas, leverage, growth, dan size berpengaruh terhadap harga saham dengan pengungkapan tanggung jawab sosial perusahaan sebagai variabel intervening pada perusahaan yang terdaftar di BEI?

\section{Tujuan Penelitian}

Tujuan diadakannya penelitian ini adalah untuk mengetahui pengaruh profitabilitas, leverage, growth, dan size secara terhadap harga saham dengan pengungkapan tanggung jawab sosial perusahaan sebagai variabel intervening pada perusahaan yang terdaftar di BEI.

\section{TINJAUAN PUSTAKA \\ Penelitian Terdahulu}

Subiyantoro dan Andreani (2003) melakukan Analisis Faktor - faktor yang mempengaruhi Harga Saham. Populasi dari penelitian ini adalah perusahaan jasa perhotelan yang terdaftar di pasar modal Indonesia sampai dengan akhir tahun 2001. Secara parsial yang berpengaruh signifikan terhadap variasi harga saham adalah book value equity per share dan return on equity.

Suwahyono dan Oetomo (2006) dengan judul penelitian Analisis Pengaruh Beberapa Variabel Fundamental Keuangan Perusahaan Terhadap Harga Saham Perusahaan Telekomunikasi Yang Tercatat di Bursa Efek Jakarta, dengan periode penelitian selama 10 tahun yaitu dari tahun 1994 sampai tahun 2004. Berdasar dari hasil penelitian ini, Secara bersama - sama variabel price earning ratio, price to book value, current ratio, debt ratio, operating profit margin, net profit margin, dan total assets turnover mempunyai pengaruh yang signifikan terhadap harga saham industri perusahaan telekomunikasi. Secara individu variabel price to book value, current ratio dan total asset turnover berpengaruh terhadap harga saham. Pengaruh yang ditimbulkan oleh variabel total assets turnover adalah searah.

Pasaribu (2008) meneliti Pengaruh Variabel Fundamental Terhadap Harga Saham Perusahaan Go Public di BEI. Populasi dalam penelitian ini menggunakan perusahaan dalam kedelapan kelompok industri yang terdaftar di Bursa Efek Indonesia. Kesimpulan yang diperoleh peneliti dari penelitian ini adalah, secara simultan dan parsial, pertumbuhan, profitabilitas, posisi leverage, likuiditas, dan efisiensi perusahaan berpengaruh signifikan terhadap harga saham didelapan industri.

Kusumawati (2009) dalam penelitiannya mengenai Pengaruh Risiko bank dan Profitabilitas Terhadap Harga Pasar Saham pada Perusahaan Perbankan, menyimpulkan Capital Adequacy Ratio/CAR, Non Performing Loan/NPL dan Return On Asset/ROA berpengaruh secara simultan atau bersama - sama 
terhadap variabel terikat yaitu HPS. Secara parsial CAR dan NPL berpengaruh negatif dan tidak signifikan terhadap harga saham; Secara parsial ROA berpengaruh secara positif dan signifikan.

Sinambela (2009) melakukan penelitian tentang Pengaruh Return On Assets (ROA), Return On Equity (ROE), Price Earning Ratio (PER), Debt to Equity Ratio (DER) terhadap Harga Saham. Perusahaan - perusahaan yang termasuk dalam penelitian adalah perusahaan - perusahaan dari berbagai bidang industri, yang termasuk dalam perhitungan indeks LQ 45 periode $2004-2007$. Dalam penelitian ini disimpulkan bahwa secara simultan ROA, ROE, PER, dan DER berpengaruh terhadap harga saham perusahaan indeks LQ 45. Dan secara parsial hanya ROA yang berpengaruh terhadap harga saham.

Deitiana (2011) melakukan penelitian terhadap perusahaan LQ45 di BEI pada periode tahun 2004 - 2008 mengenai Pengaruh rasio Keuangan, Pertumbuhan Penjualan dan Deviden Terhadap Harga Saham. Rasio keuangan yang digunakan dalam penelitian ini adalah Likuiditas (Current Ratio), Profitabilitas (Return On Equity), Pertumbuhan Penjualan, Deviden (Deviden Payout Ratio). Dari penelitian tersebut diperoleh kesimpulan bahwa profitabilitas berpengaruh terhadap harga saham sedangkan likuiditas, deviden dan pertumbuhan penjualan tidak berpengaruh terhadap harga saham.

Rusli, Tan dan Meythi (2011) meneliti pengaruh Likuiditas dan Profitabilitas Terhadap harga Saham Perusahaan Manufaktur yang terdaftar di Bursa Efek Indonesia. Sampel penelitian berjumlah 85 perusahaan manufaktur. Secara parsial, likuiditas yang diukur dengan Current Ratio dan profitabilitas yang diukur dengan Earnings Per Share (EPS) tidak berpengaruh signifikan terhadap harga saham perusahaan manufaktur. Sedangkan secara simultan likuiditas dan profitabilitas berpengaruh signifikan terhadap harga saham perusahaan manufaktur.

Susilawati (2012) melakukan penelitian pada perusahaan LQ 45 mengenai Analisis Perbandingan Pengaruh Likuiditas, Solvabilitas dan Profitabilitas terhadap Harga Saham. Dari hasil penelitian diatas dapat disimpulkan: 1. Variabel yang paling berpengaruh terhadap harga saham LQ 45 adalah profitabilitas dengan indikator ROA (Return on Asset) sebesar 40,2\%; 2. Variabel penelitian solvabilitas menunjukkan pengaruh yang signifikan terhadap harga saham LQ 45 hanya pengaruhnya kecil hanya sebesar 7,5\%; 3. Variabel penelitian likuiditas tidak menunjukkan pengaruh terhadap harga saham LQ 45.

Deitiana (2013) dalam penelitian mengenai Pengaruh Current Ratio, Return On Equity dan Total Asset Turn Over Terhadap Devidend Payout Ratio dan Implikasi Pada Harga Saham Perusahaan LQ 45 memperoleh kesimpulan bahwa tidak ada pengaruh CR, ROE terhadap DPR. Namun TATO berpengaruh terhadap DPR. CR dan TATO tidak berpengaruh terhadap Harga Saham dan ROE berpengaruh terhadap Harga Saham. Penelitian ini dilakukan pada perusahaan LQ45 yang terdaftar di BEI pada tahun 2008 2011.

Dewi dan Wirajaya (2013) melakukan penelitian terhadap 71 perusahaan manufaktur yang terdaftar di BEI tahun 2009 - 2011, mengenai Pengaruh Struktur Modal, Profitabilitas dan Ukuran Perusahaan Pada Nilai Perusahaan. Dari penelitian ini dapat disimpulkan bahwa struktur modal berpengaruh negatif dan signifikan pada nilai perusahaan, profitabilitas berpengaruh positif dan signifikan pada nilai perusahaan dan ukuran perusahaan tidak berpengaruh pada nilai perusahaan. Dalam penelitian ini harga saham digunakan sebagai ukuran Nilai Perusahaan.

Mahapsari dan Taman (2013) meneliti Pengaruh Profitabilitas, Struktur Aktiva dan Pertumbuhan Penjualan Terhadap Harga Saham dengan Struktur Modal Sebagai Variabel Intervening Pada Perusahaan Manufaktur di Bursa Efek Indonesia. 12 perusahaan manufaktur dijadikan sampel dalam penelitian ini. Kesimpulan yang diperoleh: Tidak terdapat pengaruh positif profitabilitas terhadap struktur modal; Tidak terdapat pengaruh negatif struktur aktiva terhadap struktur modal; Terdapat pengaruh positif pertumbuhan penjualan terhadap struktur modal; Tidak terdapat pengaruh negatif profitabilitas, struktur aktiva dan pertumbuhan penjualan terhadap struktur modal; Terdapat pengaruh positif profitabilitas terhadap harga saham. Tidak terdapat pengaruh positif struktur aktiva terhadap harga saham. Tidak terdapat pengaruh negatif pertumbuhan penjualan terhadap harga saham. Terdapat pengaruh negatif struktur modal terhadap harga saham. Terdapat pengaruh positif profitabilitas, struktur aktiva dan pertumbuhan penjualan terhadap harga saham melalui struktur modal.

Wijaya dan Utama (2014) meneliti tentang: Pengaruh Profitabilitas, Struktur Aset dan Pertumbuhan Penjualan Terhadap Struktur Modal Serta Harga Saham terhadap perusahaan properti dan real estate periode 2010 - 2012. Penelitian ini menggunakan 30 sampel perusahaan yang terdaftar di BEI. Berdasarkan hasil analisis data dan pembahasan, kesimpulan dalam penelitian ini adalah profitabilitas berpengaruh terhadap struktur modal, struktur aset berpengaruh terhadap struktur modal, pertumbuhan 
penjualan tidak berpengaruh terhadap struktur modal, profitabilitas berpengaruh terhadap harga saham, struktur aset tidak berpengaruh terhadap harga saham dan pertumbuhan penjualan berpengaruh terhadap harga saham.

Sembiring (2005) dalam penelitiannya mengenai Karakterikstik Perusahaan dan Pengungkapan Tanggung Jawab Sosial: Studi Empiris Pada Perusahaan yang Tercatat di Bursa Efek Jakarta. Menggunakan populasi semua perusahaan yang tercatat (go-public) di Bursa Efek Jakarta (BEJ) seperti yang tercantum dalam Indonesian Capital Market Directory 2002. Sebanyak 78 perusahaan dipilih menjadi sampel dengan menggunakan metode stratified random sampling. Dalam pengujian secara simultan, size, profitailitas, profile, ukuran dewan komisaris dan leverage mampu mempengaruhi tingkat pengungkapan tanggung jawab sosial. Size yang diproksi dengan jumlah tenaga kerja berpengaruh signifikan terhadap pengungkapan tanggung jawab sosial perusahaan. Kinerja ekonomi/profitabilitas yang diproksi dengan pendapatan per lembar saham, menunjukkan pengaruh yang tidak signifikan terhadap pengungkapan tanggung jawab sosial. Hasil penelitian ini juga menunjukkan pengaruh yang positif signifikan profile terhadap pengungkapan tanggung jawab sosial perusahaan. Ukuran dewan komisaris dalam penelitian ini menunjukkan pengaruh yang positif signifikan terhadap pengungkapan tanggung jawab sosial perusahaan. Leverage yang diproksi dengan rasio hutang terhadap modal sendiri menunjukkan pengaruh yang tidak signifikan terhadap pengungkapan tanggung jawab sosial perusahaan.

Dewi dan Sitinjak (2009) manganalisis Pengaruh Karakteristik Perusahaan Terhadap Earnings Respons Coeficient Dengan Corporate Social Responsibility Sebagai Variabel Intervening Pada Perusahaan Manufaktur Yang Terdaftar di Bursa Efek Indonesia. Populasi dalam penelitian ini adalah seluruh perusahaan manufaktur dalam Bursa Efek Indonesia. Dalam penelitian ini ditemukan bahwa pada model pertama didapat hasil bahwa profitabilitas dan ukuran perusahaan saja yang berpengaruh terhadap luas pengungkapan sosial. Sedangkan leverage tidak berpengaruh secara signifikan terhadap luas pengungkapan sosial. Pada model kedua, diketahui bahwa luas pengungkapan sosial berpengaruh secara signifikan terhadap Earning Response Coeficient (ERC) yang diukur dengan Cummulative Abnormal Return (CAR). Pada model ketiga didapat hasil perhitungan regresi yang menunjukkan bahwa hanya variabel ukuran perusahaan yang berpengaruh secara signifikan terhadap Earning Response Coeficient (ERC). Sedangkan variabel profitabilitas dan leverage tidak berpengaruh secara langsung terhadap Earning Response Coeficient (ERC). Seluruh hasil perhitungan regresi menunjukkan bahwa seluruh variabel bebas tidak ada yang menunjukkan adanya hubungan secara tidak langsung antara Corporate Social Responsibility (CSR) terhadap Earning Response Coeficient (ERC). Hal ini tidak membuktikan bahwa Corporate Social Responsibility (CSR) dapat berperan sebagai variabel intervening.

Nurkhin (2010) meneliti tentang: Corporate Governance dan Profitabilitas, Pengaruhnya terhadap Pengungkapan CSR Sosial Perusahaan. Penelitian ini menggunakan populasi seluruh perusahaan yang tercatat di Bursa Efek Indonesia tahun 2007. Berdasarkan hasil penelitian ditarik kesimpulan sebagai berikut. Pertama, kepemilikan institusional tidak terbukti berpengaruh secara signifikan terhadap pengungkapan tanggung jawab sosial perusahaan. Kedua, komposisi dewan komisaris independen dengan proksi prosentase jumlah dewan komisaris independen terbukti signifikan berpengaruh positif terhadap pengungkapan tanggung jawab sosial perusahaan. Ketiga, profitabilitas dengan proksi ROE terbukti secara signifikan berpengaruh positif terhadap pengungkapan tanggung jawab sosial perusahaan. Keempat, ukuran perusahaan sebagai variabel kendali terbukti berpengaruh secara signifikan terhadap pengungkapan tanggung jawab sosial perusahaan. Sementara variabel tipe industri tidak terbukti berpengaruh terhadap pengungkapan CSR.

Sari (2012) melakukan penelitian pada 16 Perusahaan Manufaktur yang terdaftar di Bursa Efek Indonesia. Penelitian yang dilakukan mengenai Pengaruh Karakteristik Perusahaan Terhadap Corporate Social Responsibility Disclosure. Dari hasil penelitian tersbut diperoleh kesimpulan bahwa hanya variabel profile, size dan profitabilitas yang berpengaruh signifikan terhadap Corporate Social Responsibility Disclosure dan secara simultan variabel profile, size, profitabilitas, leverage dan growth berpengaruh terhadap Corporate Social Responsibility Disclosure.

Dewi dan Keni (2013) dalam hasil penelitiannya mengenai Pengaruh Umur Perusahaan, Profitabilitas, Ukuran Perusahaan dan Leverage Terhadap Pengungkapan Tanggung Jawab Sosial Perusahaan menunjukkan bahwa profitabilitas dan ukuran perusahaan memiliki pengaruh terhadap pengungkapan tanggung jawab sosial perusahaan sedangkan umur perusahaan dan leverage tidak memiliki pengaruh terhadap pengungkapan tanggung jawab sosial perusahaan. Penelitian ini 
menggunakan sampel 105 data perusahaan manufaktur yang terdaftar di Bursa Efek Indonesia selama tahun $2009-2011$.

Ramdhaningsih dan Utama (2013) meneliti Pengaruh Indikator Good Corporate Governance Dan Profitabilitas Pada Pengungkapan Corporate Social Responsibility. Penelitian dikhususkan pada perusahaan properti dan real estate yang terdaftar di BEI tahun 2009 - 2011 dengan 30 sampel penelitian yang diperoleh menggunakan metode purposive sampling. Terkait dengan indikator GCG tersebut, proksi yang digunakan antara lain: ukuran dewan komisaris, komisaris independen, kepemilikan manajerial, dan kepemilikan institusional. Sedangkan rasio profitabilitas menggunakan rasio return on equity (ROE). Analisis regresi linear berganda digunakan sebagai teknik dalam penelitian ini. Dari hasil tersebut dapat dilihat bahwa ukuran dewan komisaris dan komisaris independen tidak berpengaruh signifikan pada pengungkapan CSR, sementara kepemilikan manajerial, kepemilikan institusional dan profitabilitas berpengaruh signifikan pada pengungkapan CSR.

Marhamah (2013) melakukan penelitian pada perusahaan manufaktur yang tercatat di Bursa Efek Indonesia tahun 2007 - 2010, mengenai Pengaruh Manajemen Laba, Ukuran Perusahaan Terhadap Corporate Social Responsibility (CSR) dan Nilai Perusahaan. Penelitian ini mengambil sampel sebanyak 37 perusahaan selama periode pengamatan 4 tahun. Tidak terdapat pengaruh yang signifikan antara manajemen laba terhadap CSR. Terdapat pengaruh positif yang signifikan antara ukuran perusahaan terhadap CSR. Tidak terdapat pengaruh yang signifikan antara manajemen laba terhadap nilai perusahaan. Tidak terdapat pengaruh positif yang signifikan antara ukuran perusahaan terhadap nilai perusahaan. Terdapat pengaruh yang signifikan antara Corporate Social Responsibility (CSR) terhadap nilai perusahaan. Corporate Social Responsibility (CSR) tidak memediasi hubungan antara manajemen laba dengan nilai perusahaan, tetapi Corporate Social Responsibility (CSR) sebagai variabel mediasi hubungan antara ukuran perusahaan dengan nilai perusahaan.

Wardani dan Januarti (2013) meneliti Pengaruh Karakteristik Perusahaan Terhadap Pengungkapan Corporate Social Responsibility, pada perusahaan manufaktur yang terdaftar di Bursa Efek Indonesia Tahun 2009 - 2011. Dari hasil analisis data dapat disimpulkan bahwa ukuran dewan komisaris memiliki pengaruh yang signifikan terhadap luas pengungkapan tanggung jawab sosial dalam laporan tahunan perusahaan. Profitabilitas perusahaan memiliki pengaruh yang signifikan terhadap luas pengungkapan tanggung jawab sosial dalam laporan tahunan perusahaan. Leverage tidak memiliki pengaruh yang signifikan terhadap luas pengungkapan tanggung jawab sosial dalam laporan tahunan perusahaan.

Putri dan Christiawan (2014) dalam penelitiannya tentang Pengaruh Profitabilitas, Likuiditas dan Leverage Terhadap Pengungkapan Corporate Social Responsibility, menyimpulkan bahwa Profitabilitas tidak berpengaruh terhadap pengungkapan CSR; Likuiditas tidak berpengaruh positif terhadap pengungkapan CSR; dan Leverage tidak berpengaruh terhadap pengungkapan CSR. Penelitian ini dilakukan pada perusahaan - perusahaan yang mendapat penghargaan ISRA (Indonesia Sustainability Report Awards) dan terdaftar di Bursa Efek Indonesia tahun 2010 - 2012.

\section{Landasan Teori}

\section{Teori Agency}

Jensen dan Meckling (1976) dalam Ramdhaningsih dan Utama (2013) menyatakan konsep keagenan yaitu sebuah kontrak yang dimana principal menyewa agent untuk melakukan kontribusi bagi kepentingan mereka dengan memberikan beberapa wewenang pembuatan keputusan kepada agent. Keberhasilan agent dapat dilihat dari kinerja keuangan perusahaan, diantaranya: Profitabilitas, leverage, growth, dan size. Rasio-rasio keuangan dalam laporan keuangan perusahaan mencerminkan kinerja keuangan perusahaan yang menjadi dasar pertimbangan para investor. Pengungkapan tanggung jawab sosial merupakan salah satu komitmen manajemen untuk meningkatkan kinerjanya terutama dalam kinerja sosial. Dengan demikian, manajemen akan mendapatkan penilaian positif dari stakeholders (Wardani dan Januarti, 2013).

\section{Teori Signaling}

Godfrey et al. (2006) dalam Rusli, Tan dan Meythi (2011) mengatakan teori signal berbicara mengenai manajer yang menggunakan akun-akun dalam laporan keuangan untuk memberikan tanda atau signal harapan dan tujuan masa depan. Dengan laporan keuangan menjadi bahan pertimbangan investor, maka investor akan melakukan analisis terhadap laporan keuangan misalnya : Profitabilitas, leverage, growth, dan size. Salah satu informasi yang wajib untuk diungkapkan oleh perusahaan adalah informasi 
tentang tanggung jawab sosial perusahaan. Perusahaan melakukan pengungkapan CSR dengan harapan dapat meningkatkan reputasi dan nilai perusahaan (Rustiarini, 2010 dalam Putri \& Christiawan, 2014).

\section{Teori Stakeholder}

Stakeholder merupakan semua pihak yang keberadaannya sangat mempengaruhi dan dipengaruhi perusahaan, seperti: karyawan, masyarakat, perusahaan pesaing dan pemerintah (Purwanto, 2011). Pengungkapan tanggung jawab sosial bagi suatu perusahaan sangatlah penting, karena para stakeholders perlu untuk mengevaluasi dan mengetahui sejauh mana perusahaan dalam melaksanakan peranannya sesuai dengan keinginan stakeholders, sehingga menuntut adanya akuntabilitas perusahaan atas kegiatan tanggung jawab sosial yang telah dilakukannya (Riswari,2012).

\section{Teori Legitimasi}

Haniffa dan Cooke (2005) menyimpulkan teori legitimasi sebagai asumsi yang pada umumnya adalah tindakan-tindakan suatu entitas yang merupakan sistem dari norma-norma, nilai-nilai, kepercayaan-kepercayaan dan definisi diinginkan, layak dan jelas yang dibangun secara sosial. Pengungkapan tanggung jawab social perusahan digunakan untuk melegitimasi aktivitas perusahaan di mata masyarakat, karena pengungkapan tanggung jawab sosial akan menunjukkan tingkat kepatuhan suatu perusahaan (Branco dan Rodrigues, 2008).

\section{Profitabilitas}

Profitabilitas adalah kemampuan perusahaan untuk menghasilkan laba selama satu tahun dan dikalkulasikan dengan return on equity. Return on Equity (ROE), yang sering disebut juga Return on Net Worth, mengukur profitabilitas perusahaan dibandingkan terhadap jumlah modal ekuitas. Rasio ini terkait dengan keuntungan perusahaan terhadap sumber ekuitas (Neveu, 1985).

\section{Leverage}

Rasio hutang atau leverage menunjukkan seberapa besar kebutuhan dana perusahaan dibelanjai dengan hutang. Apabila perusahaan tidak mempunyai leverage atau rasio leverage-nya bernilai nol, artinya perusahaan beroperasi sepenuhnya menggunakan modal sendiri tanpa menggunakan hutang (Rusli, Tan dan Meythi (2011).

\section{Growth}

Pertumbuhan penjualan (Growth) mencerminkan manifestasi keberhasilan investasi periode masa lalu dan dapat dijadikan prediksi pertumbuhan masa yang akan datang. Pertumbuhan penjualan juga merupakan indikator permintaan dan daya saing perusahaan dalam suatu industri. Laju pertumbuhan suatu perusahaan akan mempengaruhi kemampuan mempertahankan keuntungan dalam mendanai kesempatan-kesempatan pada masa yang akan datang (Barton et al. 1989).

\section{Harga Saham}

Saham dapat didefinisikan sebagai tanda penyertaan atau kepemilikan seseorang atau badan dalam suatu perusahaan atau perseroan terbatas. Wujud saham adalah selembar kertas yang menerangkan bahwa pemilik kertas tersebut adalah pemilik perusahaan yang menerbitkan surat berharga tersebut. Porsi kepemilikan ditentukan oleh seberapa besar penyertaan yang ditanamkan di perusahaan tersebut (Darmadji dan Fakhruddin, 2001).

\section{Pengungkapan Tanggung Jawab Sosial Perusahaan}

Elkington (1997) menyebutkan bahwa tanggung jawab sosial perusahaan mencakup tiga dimensi yang lebih populer dengan singkatan 3P yaitu mencapai keuntungan (profit) bagi perusahaan, memberdayakan masyarakat (people) dan memelihara kelestarian alam/bumi (planet). Menurut Nurkhin (2010) tanggung jawab sosial perusahaan merupakan sebuah gagasan yang menjadikan perusahaan tidak lagi dihadapkan pada tanggung jawab yang berpijak pada single bottom line yaitu nilai perusahaan yang direfleksikan dalam kondisi keuangan saja tapi tanggung jawab perusahaan harus berpijak pada triple bottom line yaitu juga memperhatikan masalah sosial dan lingkungan (Dewi dan Keni, 2013). 


\section{KERANGKA KONSEPTUAL}

\section{Kerangka Konseptual Penelitian}

Berdasarkan pemikiran dan uraian pada bab II, maka kerangka konseptual dalam penelitian ini, dapat digambarkan sebagai berikut :
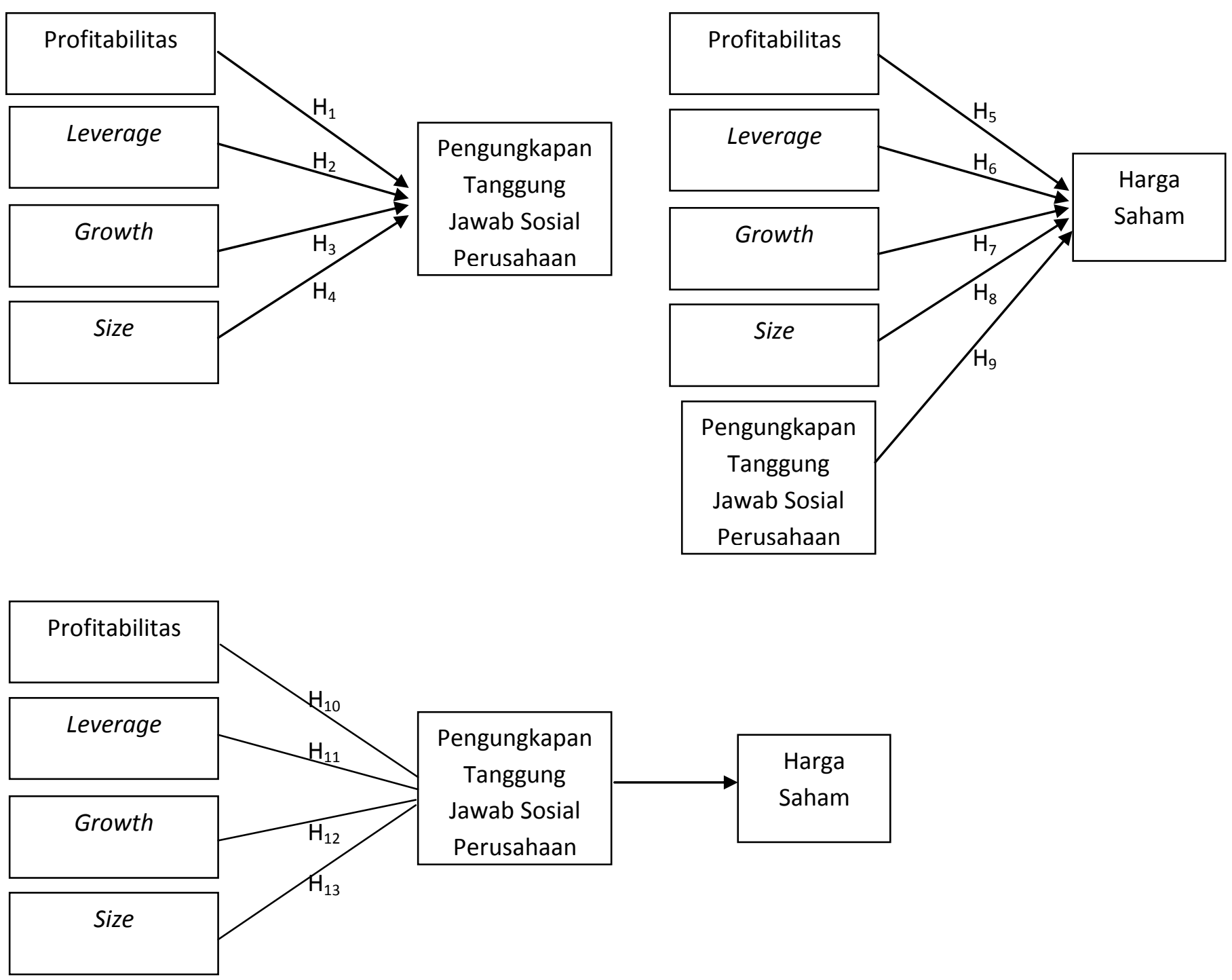

\section{Hipotesis Penelitian}

1. Pengaruh Profitabilitas terhadap Pengungkapan Tanggung Jawab Sosial Perusahaan

Profitabilitas Perusahaan memiliki pengaruh yang signifikan terhadap luas pengungkapan tanggung jawab sosial. (Wardani dan Januarti, 2013). Hal ini berbeda dengan hasil penelitian dan Echave dan Shyam (2010) yang menyatakan bahwa Profitabilitas tidak berpengaruh secara signifikan terhadap pengungkapan tanggung jawab sosial perusahaan. Berdasarkan perbedaan hasil penelitian sebelumnya maka peneliti melakukan penelitian dengan hipotesis:

$\mathrm{H}_{1}$ : Profitabilitas berpengaruh terhadap pengungkapan tanggung jawab sosial perusahaan yang terdaftar di BEI.

2. Pengaruh Leverage terhadap Pengungkapan Tanggung Jawab Sosial Perusahaan

Dalam penelitiannya Politon dan Rustiyaningsih (2013) menyatakan bahwa leverage berpangaruh positif dan tidak signifikan terhadap pengungkapan tanggung jawab sosial perusahaan, berbeda dengan hasil penelitian Wardani dan Januarti (2013) dan Echave dan Shyam (2010) yang menyatakan bahwa leverage tidak berpengaruh secara signifikan terhadap pengungkapan tanggung jawab sosial perusahaan. Berdasarkan perbedaan hasil penelitian sebelumnya maka peneliti melakukan penelitian dengan hipotesis:

$\mathrm{H}_{2}$ : Leverage berpengaruh terhadap pengungkapan tanggung jawab sosial perusahaan yang terdaftar di BEI. 


\section{Pengaruh Growth terhadap Pengungkapan Tanggung Jawab Sosial Perusahaan}

Maria Ulfa (2009) dalam Sari (2012) menyatakan bahwa growth Perusahaan dengan pertumbuhan tinggi akan mendapat banyak sorotan sehingga diprediksi perusahaan yang mempunyai kesempatan pertumbuhan yang lebih tinggi cenderung lebih banyak melakukan Corporate Social Responsibility Disclosure. Namun dalam penelitiannya Ekowati dkk (2014) menyimpulkan bahwa growth tidak mempengaruhi pengungkapan tanggung jawab sosial perusahaan. Berdasarkan perbedaan hasil penelitian sebelumnya maka peneliti melakukan penelitian dengan hipotesis:

$\mathrm{H}_{3}$ : Growth berpengaruh terhadap pengungkapan tanggung jawab sosial perusahaan yang terdaftar di BEI.

4. Pengaruh Size terhadap Pengungkapan Tanggung Jawab Sosial Perusahaan

Ukuran perusahaan memiliki pengaruh positif signifikan terhadap pengungkapan tanggung jawab sosial. (Wijaya, 2012). Berbeda dengan penelitian yang dilakukan oleh Echave dan Shyam (2010) dan Bayoud (2011) bahwa ukuran perusahaan tidak memiliki pengaruh yang signifikan terhadap pengungkapan tanggung jawab sosial perusahaan. Berdasarkan perbedaan hasil penelitian sebelumnya maka peneliti melakukan penelitian dengan hipotesis:

$\mathrm{H}_{4}$ : Size berpengaruh terhadap pengungkapan tanggung jawab sosial perusahaan yang terdaftar di BEI.

5. Pengaruh Profitabilitas terhadap Harga Saham

Wijaya dan Utama (2014) dalam penelitiannya menyatakan bahwa profitabilitas berpengaruh terhadap harga saham, hal ini berbeda dengan Rusli (2011) dan Sinambela (2009) yang menyatakan bahwa profitabilitas tidak berpengaruh terhadap harga saham. Berdasarkan perbedaan hasil penelitian sebelumnya maka peneliti melakukan penelitian dengan hipotesis:

H$_{5}$ : Profitabilitas berpengaruh terhadap harga saham perusahaan yang terdaftar di BEI.

6. Pengaruh Leverage terhadap Harga Saham

Dalam penelitian yang dilakukan Pasaribu (2008) diketahui bahwa Leverage berpengaruh terhadap harga saham, namun Leverage dinyatakan tidak berpengaruh terhadap harga saham dalam penelitian yang dilakukan oleh Sinambela (2009) serta Suwahyono dan Oetomo (2003). Berdasarkan perbedaan hasil penelitian sebelumnya maka peneliti melakukan penelitian dengan hipotesis:

$\mathrm{H}_{6}$ : Leverage berpengaruh terhadap harga saham perusahaan yang terdaftar di BEI.

7. Pengaruh Growth terhadap Harga Saham

Pasaribu (2008) mengemukakan bahwa pertumbuhan penjualan berpengaruh terhadap harga saham, hal ini juga dikemukakan oleh Wijaya dan Utama (2014). Sementara itu Deitiana (2011) mengemukakan bahwa pertumbuhan penjualan tidak berpengaruh terhadap harga saham. Berdasarkan perbedaan hasil penelitian sebelumnya maka peneliti melakukan penelitian dengan hipotesis:

$\mathrm{H}_{7}$ : Growth berpengaruh terhadap harga saham perusahaan yang terdaftar di BEI.

8. Pengaruh Size terhadap Harga Saham

Chaney dan Jeter (1991) yang dikutip oleh Dewi \& Sitinjak (2009) menunjukkan bahwa besaran perusahaan berpengaruh secara signifikan negatif terhadap ERC. Laily (2013) menyatakan bahwa ukuran perusahaan tidak berpengaruh secara signifikan terhadap harga saham. Berdasarkan perbedaan hasil penelitian sebelumnya maka peneliti melakukan penelitian dengan hipotesis:

$\mathrm{H}_{8}$ : Size berpengaruh terhadap harga saham perusahaan yang terdaftar di BEI.

9. Pengaruh Pengungkapan Tanggung Jawab Sosial Perusahaan terhadap Harga Saham

Retno (2012) menyimpulkan dalam penelitiannya bahwa pengungkapan tanggung jawab sosial berpengaruh positif dan tidak signifikan terhadap nilai perusahaan dengan variabel kontrol ukuran perusahaan, jenis industri, profitabilitas, dan leverage pada perusahaan yang terdaftar di BEI periode 2007-2010. Penelitian lainnya juga menyimpulkan bahwa pengungkapan tanggung jawab sosial perusahaan berpengaruh positif dan signifikan terhadap nilai perusahaan manufaktur yang terdaftar di BEI tahun 2008-2012 dan profitabilitas mampu memperkuat pengaruh pengungkapan tanggung jawab sosial perusahaan terhadap nilai perusahaan. (Rosiana dkk, 2013). Hasil penelitian berbeda menunjukkan bahwa pengungkapan tanggung jawab sosial perusahaan tidak berpengaruh signifikan terhadap nilai perusahaan. (Agustine 2014). Wardhani (2013) juga menyimpulkan bahwa pengungkapan tanggung jawab sosial perusahaan tidak memiliki pengaruh signifikan terhadap nilai perusahaan. Berdasarkan perbedaan hasil penelitian sebelumnya maka peneliti melakukan penelitian dengan hipotesis: 
Hy: $_{\text {: }}$ Pengungkapan tanggung jawab sosial perusahaan berpengaruh terhadap harga saham perusahaan yang terdaftar di BEI.

10. Pengaruh Profitabilitas terhadap Harga Saham dengan Pengungkapan Tanggung Jawab Sosial sebagai Variabel Intervening

Profitabilitas berpengaruh terhadap harga saham dalam penelitian Pasaribu (2008), Deitiana (2011), Susilawati (2012), Asnita (2013), Mahapsari dan Taman (2013), Dewi dan Wirajaya (2013), Deitiana (2013), Wijaya dan Utama (2014). Hasil yang berbeda dikemukakan oleh Sinambela (2009) dan Rusli (2011) yang menyatakan profitabilitas tidak berpengaruh terhadap harga saham. Anugerah dkk (2010), Nurkhin (2010), Politon dan Rustiyaningsih (2013), Wardani dan Januarti (2013) menyatakan profitabilitas berpengaruh terhadap pengungkapan tanggung jawab sosial perusahaan Namun profitabilitas tidak berpengaruh terhadap pengungkapan tanggung jawab sosial perusahaan dalam hasil penelitian Wijaya (2012), Sembiring (2003), Sembiring (2005), Sriayu dan Mimba (2013). Semakin tinggi tingkat pengungkapan tanggung jawab sosial perusahaan maka juga dapat meningkatkan nilai perusahaan (Marhamah, 2013 ; Retno dan Priantinah, 2012). Hasil ini berbeda dengan Wardhani (2013) yang menyatakan tidak ada pengaruh pengungkapan tanggung jawab sosial perusahaan terhadap harga saham. Berdasarkan hasil penelitian sebelumnya maka peneliti melakukan penelitian dengan hipotesis:

$\mathrm{H}_{10}$ :Profitabilitas berpengaruh terhadap harga saham melalui pengungkapan tanggung jawab sosial perusahaan yang terdaftar di BEI.

11. Pengaruh Leverage terhadap Harga Saham dengan Pengungkapan Tanggung Jawab Sosial sebagai Variabel Intervening

Pasaribu (2008) menyatakan bahwa secara parsial leverage berpengaruh terhadap harga saham di delapan industry, berbeda dengan Sinambela (2009) yang menyatakan bahwa tidak ada pengaruh leverage terhadap harga saham.

Tingkatan leverage akan mempengaruhi perusahaan dalam pengungkapan tanggung jawab sosialnya, hal ini menjadi kesimpulan dalam penelitian, Anugerah dkk (2010), Politon dan Rustiyaningsih (2013). Namun bertolak belakang dengan kesimpulan Sembiring (2003), Sriayu dan Mimba (2013) dalam penelitiannya. Semakin tinggi tingkat pengungkapan tanggung jawab sosial perusahaan maka juga dapat meningkatkan nilai perusahaan (Marhamah, 2013 ; Retno dan Priantinah, 2012). Hasil ini berbeda dengan Wardhani (2013) yang menyatakan tidak ada pengaruh pengungkapan tanggung jawab sosial perusahaan terhadap harga saham. Berdasarkan hasil penelitian sebelumnya maka peneliti melakukan penelitian dengan hipotesis:

$\mathrm{H}_{11}$ :Leverage berpengaruh terhadap harga saham melalui pengungkapan tanggung jawab sosial perusahaan yang terdaftar di BEI.

12. Pengaruh Growth terhadap Harga Saham dengan Pengungkapan Tanggung Jawab Sosial sebagai Variabel Intervening

Wijaya dan Utama (2014) mengemukakan bahwa pertumbuhan penjualan mempengaruhi nilai perusahaan atau harga saham perusahaan, sama halnya dengan Pasaribu (2008). Berbeda dengan pernyataan sebelumnya, Deitiana (2011), Mahapsari dan Taman (2013) mengemukakan bahwa growth tidak berpengaruh terhadap harga saham. Perusahaan dengan growth tinggi akan mendapat banyak sorotan sehingga cenderung lebih banyak melakukan tanggung jawab sosial perusahaan, namun Ekowati dkk (2012) dalam penelitiannya menunjukkan bahwa growth tidak mempengaruhi pengungkapan tanggung jawab sosial perusahaan. Semakin tinggi tingkat pengungkapan tanggung jawab sosial perusahaan maka juga dapat meningkatkan nilai perusahaan (Marhamah, 2013 ; Retno dan Priantinah, 2012). Hasil ini berbeda dengan Wardhani (2013) yang menyatakan tidak ada pengaruh pengungkapan tanggung jawab sosial perusahaan terhadap harga saham. Berdasarkan hasil penelitian sebelumnya maka peneliti melakukan penelitian dengan hipotesis:

$\mathrm{H}_{12}$ :Growth berpengaruh terhadap harga saham melalui pengungkapan tanggung jawab sosial perusahaan yang terdaftar di BEI.

13. Pengaruh Size terhadap Harga Saham dengan Pengungkapan Tanggung Jawab Sosial sebagai Variabel Intervening

Hasil penelitian Nuraina (2012), Dewi dan Wirajaya (2013) menunjukkan bahwa variable size berpengaruh terhadap nilai perusahaan. Berbeda dengan hasil yang ditunjukkan oleh Marhamah (2013) bahwa tidak ada pengaruh yang positif dan signifikan antara ukuran perusahaan dan nilai perusahaan. 
Penelitian yang dilakukan oleh Sembiring (2005) menemukan pengaruh positif ukuran perusahaan (size) terhadap pengungkapan tanggung jawab sosial perusahaan. Penelitian ini sejalan dengan hasil penelitian Anugerah dkk (2010), Nurkhin (2010), Wijaya (2012), Politon dan Rustiyaningsih (2010), Marhamah (2013), Sriayu dan Mimba (2013). Semakin tinggi tingkat pengungkapan tanggung jawab sosial perusahaan maka juga dapat meningkatkan nilai perusahaan (Marhamah, 2013 ; Retno dan Priantinah, 2012). Hasil ini berbeda dengan Wardhani (2013) yang menyatakan tidak ada pengaruh pengungkapan tanggung jawab sosial perusahaan terhadap harga saham. Berdasarkan hasil penelitian sebelumnya maka peneliti melakukan penelitian dengan hipotesis:

$\mathrm{H}_{13}$ : Size berpengaruh terhadap harga saham melalui pengungkapan tanggung jawab sosial perusahaan yang terdaftar di BEI.

\section{Model Analisis}

Pengujian dalam penelitian ini menggunakan metode analisis jalur dan pemrosesan data menggunakan IBM SPSS Statistics 20.

\section{METODE PENELITIAN}

\section{Data, Populasi, dan Sampel}

Dalam penelitian ini data yang digunakan adalah data laporan keuangan dan laporan tahunan perusahaan yang terdaftar di BEI periode 2010 - 2012 yang diperoleh dari lembaga pengumpul data dan kepustakaan dalam hal ini Bursa Efek Indonesia (BEI). Populasi dalam penelitian ini adalah perusahaan yang terdaftar di BEI pada tahun 2010 - 2012. Sampel dipilih menggunakan Judgement Sampling, dengan kriteria-kriteria :

1. Perusahaan yang terdaftar di Bursa Efek Indonesia sejak tahun 2010 sampai dengan tahun 2012.

2. Perusahaan mempublikasikan secara lengkap laporan keuangan tahunan dan laporan tahunannya selama tahun 2010 sampai dengan tahun 2012 berturut-turut.

3. Perusahaan yang mempublikasikan laporan keuangan tahunan dalam mata uang asing, maka akan ditranslasikan ke mata uang rupiah dengan kurs tengah per tanggal neraca.

4. Perusahaan mengungkapkan laporan tanggung jawab social perusahaan dalam laporan tahunan untuk periode akuntansi tahun 2010 sampai dengan tahun 2012 yang dapat diakses melalui website Bursa Efek Indonesia (www.idx.co.id).

5. Perusahaan yang tidak mengalami rugi atau pertumbuhan penjualan (Growth) negatif selama tahun 2010 sampai dengan tahun 2012.

\section{Pengukuran dan Definisi Operasional Variabel}

\begin{tabular}{|c|c|c|c|c|}
\hline $\mathbf{N}$ & \multicolumn{2}{|c|}{ Variabel } & Definisi Operasional & Pengukuran \\
\hline 1 & Profitabilitas & $\mathrm{X}_{1}$ & $\begin{array}{l}\text { Kemampuan perusahaan dalam } \\
\text { memperoleh laba (profit) pada periode } \\
\text { tertentu yang terdapat dalam laporan } \\
\text { keuangan tahunan perusahaan publik di } \\
\text { Indonesia. }\end{array}$ & $\begin{array}{l}\text { Profitabilitas menggunakan proksi return on equity yang } \\
\text { diperoleh dari rasio perbandingan antara Net Income dan } \\
\text { Shareholder's Equity yang tercantum dalam laporan } \\
\text { keuangan tahunan perusahaan tahun } 2010-2012 \text {. }\end{array}$ \\
\hline 2 & Leverage & $\mathrm{X}_{2}$ & $\begin{array}{l}\text { Menunjukkan seberapa besar } \\
\text { kebutuhan dana perusahaan dibelanjai } \\
\text { dengan hutang. Dapat menggambarkan } \\
\text { struktur modal perusahaan dan } \\
\text { mengetahui resiko tak tertagihnya } \\
\text { suatu utang perusahaan. }\end{array}$ & $\begin{array}{l}\text { Leverage menggunakan proksi debt to equity ratio yang } \\
\text { diperoleh dari rasio total kewajiban terhadap ekuitas } \\
\text { sendiri yang tercantum dalam laporan keuangan tahunan } \\
\text { perusahaan tahun } 2010-2012 \text {. }\end{array}$ \\
\hline 3 & Growth & $\mathrm{X}_{3}$ & $\begin{array}{l}\text { Peningkatan kinerja keuangan } \\
\text { perusahaan yang diukur dengan } \\
\text { pertumbuhan penjualan perusahaan dan } \\
\text { tercermin dalam laporan keuangan } \\
\text { tahunan perusahaan. }\end{array}$ & $\begin{array}{l}\text { Growth diukur dengan pertumbuhan penjualan } \\
\text { perusahaan menggunakan rumus penjualan bersih (net } \\
\text { sales) periode tahun berjalan dikurangi penjualan bersih } \\
\text { tahun sebelumnya dan dibagi dengan penjualan bersih } \\
\text { tahun sebelumnya menggunakan data yang tercantum } \\
\text { dalam laporan keuangan tahunan perusahaan tahun } 2010 \\
\text { - } 2012 \text {. }\end{array}$ \\
\hline 4 & Size & $\mathrm{X}_{4}$ & $\begin{array}{l}\text { Variabel untuk menilai ukuran } \\
\text { perusahaan, yang menunjukkan nilai } \\
\text { total aset perusahaan dalam laporan } \\
\text { keuangan perusahaan publik. }\end{array}$ & $\begin{array}{l}\text { Size dinilai menggunakan Log of total assets value. } \\
\text { Proksi ini digunakan untuk mentransformasi data total } \\
\text { aset sampel perusahaan yang beragam. sesuai dengan } \\
\text { yang dilaporkan dalam laporan keuangan tahun } 2010 \text { - } \\
2012 \text {. }\end{array}$ \\
\hline
\end{tabular}




\begin{tabular}{|c|c|c|c|c|}
\hline $\mathbf{N}$ & \multicolumn{2}{|l|}{ Variabel } & Definisi Operasional & Pengukuran \\
\hline 5 & $\begin{array}{c}\text { Pengungkapan } \\
\text { Tanggung } \\
\text { Jawab Sosial }\end{array}$ & $\mathrm{Y}_{1}$ & $\begin{array}{l}\text { Pengungkapan informasi terkait } \\
\text { dengan aktivitas tanggung jawab sosial } \\
\text { perusahaan yang diungkapkan dalam } \\
\text { laporan tahunan perusahaan. Luas } \\
\text { pengungkapan tanggung jawab sosial } \\
\text { diukur dengan membandingkan jumlah } \\
\text { pengungkapan yang dilakukan dengan } \\
\text { jumlah pengungkapan yang } \\
\text { diharapkan. }\end{array}$ & $\begin{array}{l}\text { Pengungkapan tanggung jawab sosial perusahaan dinilai } \\
\text { dengan menggunakan Checklist terhadap tujuh kategori } \\
\text { tanggung jawab sosial perusahaan yang diungkapkan } \\
\text { yaitu: lingkungan, energi, kesehatan dan keselamatan } \\
\text { tenaga kerja, lain - lain tenaga kerja, produk, } \\
\text { keterlibatan masyarakat, dan umum. Pendekatan ini } \\
\text { pada dasarnya menggunakan pendekatan dikotomi yaitu } \\
\text { setiap item tanggung jawab sosial dalam instrumen } \\
\text { penelitian diberi nilai } 1 \text { jika diungkapkan, dan nilai } 0 \\
\text { jika tidak diungkapkan. Selanjutnya, skor dari setiap } \\
\text { item dijumlahkan untuk memperoleh keseluruhan skor } \\
\text { untuk setiap perusahaan. Informasi yang diungkapkan } \\
\text { dalam laporan tahunan perusahaan tahun } 2010-2012 \text {. }\end{array}$ \\
\hline 6 & Harga Saham & $\mathrm{Y}_{2}$ & $\begin{array}{l}\text { Harga saham yang akan digunakan dalam } \\
\text { penelitian ini adalah harga saham pada saat } \\
\text { penutupan (closing price) pada periode } \\
\text { pengamatan. harga penutupan } \\
\text { merupakan harga saham terakhir kali } \\
\text { pada saat berpindah tangan di akhir } \\
\text { perdagangan }\end{array}$ & $\begin{array}{l}\text { Harga Saham pada penelitian ini menggunakan harga } \\
\text { penutupan saham dimana data yang diambil adalah harga } \\
\text { saham harian pada periode tiga hari sebelum sampai dengan tiga } \\
\text { hari sesudah tanggal publikasi laporan keuangan. Kemudian } \\
\text { untuk masing - masing data saham harian tersebut } \\
\text { diambil nilai rata - ratanya. }\end{array}$ \\
\hline
\end{tabular}

\section{HASIL PENELITIAN DAN PEMBAHASAN \\ Hasil Penelitian}

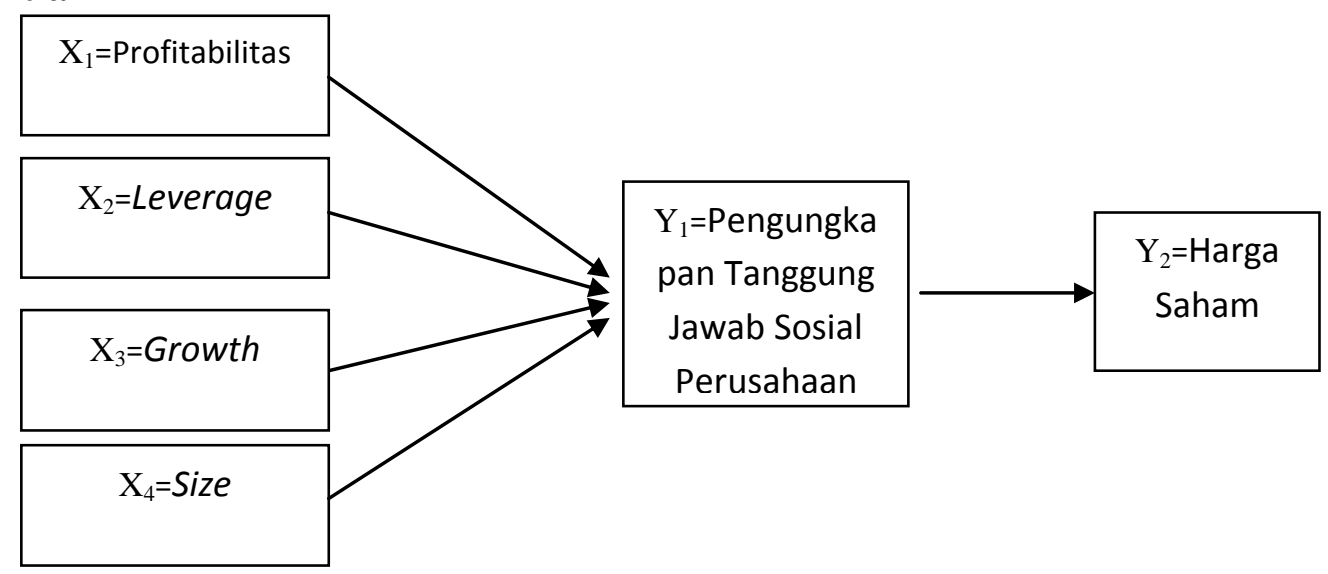

Analisis ini terdiri dari dua langkah, analisis untuk substruktural 1 dan untuk substruktural 2.

Menentukan Besarnya Koefisien Determinasi (R Square $/ \mathbf{R}^{2}$ )

Substruktural 1

Tabel 5.6 Koefisien Determinasi

\begin{tabular}{|c|c|c|c|c|c|}
\hline \multicolumn{6}{|c|}{ Model Summary ${ }^{\mathrm{b}}$} \\
\hline Model & $\mathrm{R}$ & R Square & Adjusted R Square & $\begin{array}{l}\text { Std. Error of the } \\
\text { Estimate }\end{array}$ & Durbin-Watson \\
\hline 1 & $.380^{\mathrm{a}}$ & .144 & .123 & .1245424 & 2.133 \\
\hline
\end{tabular}

a. Predictors: (Constant), SIZE, GROWTH, PROFITABILITAS, LEVERAGE

b. Dependent Variable: CSRD

(Sumber : Hasil Olah SPSS)

\section{Substruktural 2}

Tabel 5.7 Koefisien Determinasi

\begin{tabular}{|c|c|c|c|c|c|}
\hline \multicolumn{6}{|c|}{ Model Summary ${ }^{\mathrm{b}}$} \\
\hline Model & $\mathrm{R}$ & R Square & Adjusted R Square & $\begin{array}{l}\text { Std. Error of the } \\
\text { Estimate }\end{array}$ & Durbin-Watson \\
\hline 1 & $623^{\mathrm{a}}$ & .388 & .369 & 1.61854 & 1.682 \\
\hline
\end{tabular}

a. Predictors: (Constant), CSRD, LEVERAGE, GROWTH, PROFITABILITAS, SIZE

b. Dependent Variable: PRICE

(Sumber : Hasil Olah SPSS) 
Pengujian Hipotesis

Substruktural 1

a. Uji Simultan (Uji F)

Tabel 5.8 Hasil Uji Simultan (Uji F)

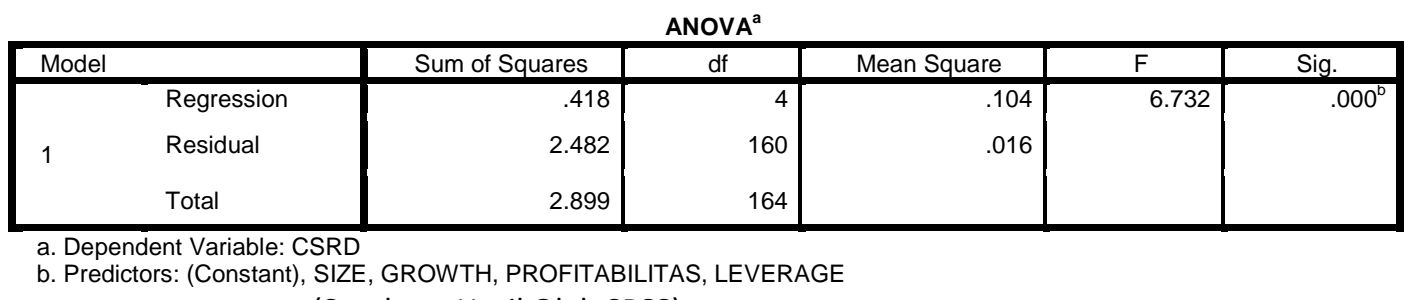

(Sumber : Hasil Olah SPSS)

b. Uji Parsial (Uji t)

Tabel 5.9 Hasil Uji Parsial (Uji t)

Coefficients $^{\mathrm{a}}$

\begin{tabular}{|c|c|c|c|c|c|c|}
\hline \multirow[t]{2}{*}{ Mod } & & \multicolumn{2}{|c|}{ Unstandardized Coefficients } & \multirow{2}{*}{$\begin{array}{c}\text { Standardized } \\
\text { Coefficients } \\
\text { Beta }\end{array}$} & \multirow[t]{2}{*}{$\mathrm{t}$} & \multirow[t]{2}{*}{ Sig. } \\
\hline & & B & Std. Error & & & \\
\hline \multirow{5}{*}{1} & (Constant) & -.466 & .155 & & -3.012 & .003 \\
\hline & PROFITABILITAS & .077 & .057 & .102 & 1.346 & 180 \\
\hline & LEVERAGE & -.012 & .005 & -.229 & -2.727 & .007 \\
\hline & GROWTH & -.016 & .013 & -.085 & -1.168 & 245 \\
\hline & SIZE & .025 & .005 & .384 & 4.488 & .000 \\
\hline
\end{tabular}

(Sumber : Hasil Olah SPSS)

Substruktural 2

a. Uji Simultan (Uji F)

Tabel 5.10 Hasil Uji Simultan (Uji F)

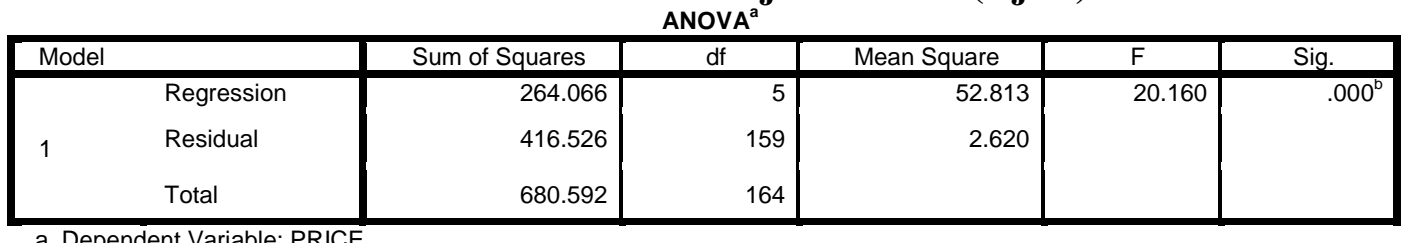

b. Predictors: (Constant), CSRD, LEVERAGE, GROWTH, PROFITABILITAS, SIZE

(Sumber : Hasil Olah SPSS)

b. Uji Parsial (Uji t)

Tabel 5.11 Hasil Uji Parsial (Uji t)

Coefficients $^{\mathrm{a}}$

\begin{tabular}{|c|c|c|c|c|c|c|}
\hline \multirow[t]{2}{*}{ Mod } & & \multicolumn{2}{|c|}{ Unstandardized Coefficients } & Standardized & \multirow[t]{2}{*}{$t$} & \multirow[t]{2}{*}{ Sig. } \\
\hline & & B & Std. Error & Beta & & \\
\hline \multirow{6}{*}{1} & (Constant) & -8.795 & 2.067 & & -4.256 & .000 \\
\hline & PROFITABILITAS & 3.428 & .743 & .297 & 4.612 & .000 \\
\hline & LEVERAGE & -.193 & .060 & -.234 & -3.217 & .002 \\
\hline & GROWTH & -.233 & 175 & -.083 & -1.333 & .184 \\
\hline & SIZE & .560 & .075 & .572 & 7.427 & .000 \\
\hline & CSRD & -.770 & 1.027 & -.050 & -.750 & .455 \\
\hline
\end{tabular}

(Sumber : Hasil Olah SPSS)

\section{Pembahasan}

Dari hasil pengujian substruktural 1 di atas diketahui bahwa secara simultan profitabilitas, leverage, growth, dan size, mempunyai pengaruh yang signifikan terhadap Pengungkapan tanggung jawab sosial perusahaan. Hal ini didasarkan pada perbandingan $\mathrm{F}_{\text {hitung }}$ dengan $\mathrm{F}_{\text {tabel }}$ dan signifikansi hitung berada di angka 0,05. Berdasarkan hasil pengujian statistik Uji Simultan (Uji F) $F_{\text {hitung }}$ diperoleh angka $6,732>$ dari $F_{\text {tabel }} 2,43$ dan sig. hitung $0,000<0,05(\alpha: 5 \%)$. Angka $R$ Square yaitu 0,144 merupakan angka pengkuadratan dari koefisien korelasi atau $(0.380)^{2}=0,144$. R Square biasa disebut dengan koefisien determinasi, angka tersebut berarti $14 \%$ pengungkapan tanggung jawab sosial dapat dijelaskan oleh variabel profitabilitas, leverage, growth, dan size. Sedangkan sisanya $(100 \%-14 \%=86 \%)$ disebabkan oleh faktor-faktor lain. Faktor-raktor lain yang dimaksud antara lain adalah ukuran dewan 
komisaris, komposisi dewan komisaris, profil perusahaan, kepemilikan manajerial, kepemilikan intitusional dan lain sebagainya.

Hasil uji statistik variabel profitabilitas $\left(\mathrm{X}_{1}\right) \mathrm{t}_{\text {hitung }}$ dan sig. hitung diperoleh angka $1,346<\mathrm{t}_{\text {tabel }}$ 1,654 dan sig. hitung $0,180>0,05(\alpha: 5 \%)$ dengan demikian profitabilitas $\left(\mathrm{X}_{1}\right)$ tidak berpengaruh signifikan terhadap pengungkapan tanggung jawab sosial perusahaan $\left(\mathrm{Y}_{1}\right)$. Hasil penelitian ini sejalan dengan hasil penelitian yang dilakukan oleh Sembiring (2005) dan Putri dan Christiawan (2014). Namun berbeda dengan penelitian yang dilakukan oleh Dewi dan Sitinjak (2009), Nurkhin (2010), Sari (2012), Dewi dan Keni (2013), Ramdhaningsih dan Utama (2013), Wardani dan Januarti (2013). Profitabilitas tidak berpengaruh terhadap pengungkapan tanggung jawab sosial karena perusahaan mengungkapkan tanggung jawab sosialnya untuk memenuhi tuntutan stakeholder, sehingga luas pengungkapan tanggung jawab sosial perusahaan tidak dipengaruhi oleh tinggi rendahnya profitabilitas melainkan kebutuhan stakeholder akan informasi mengenai tanggung jawab social yang dilakukan perusahaan.

Hasil uji statistik variabel leverage $\left(\mathrm{X}_{2}\right) \mathrm{t}_{\text {hitung }}$ dan sig. hitung diperoleh angka 2,727 $>\mathrm{t}_{\text {tabel }} 1,654$ dan sig. hitung $0,007<0,05(\alpha: 5 \%)$ dengan demikian leverage $\left(\mathrm{X}_{2}\right)$ berpengaruh signifikan terhadap pengungkapan tanggung jawab sosial perusahaan $\left(\mathrm{Y}_{1}\right)$. Hasil penelitian ini berbeda dengan Sembiring (2005), Dewi dan Sitinjak (2009), Sari (2012), Dewi dan Keni (2013), Wardani dan Januarti 2013, dan Putri dan Christiawan (2014). Teori keagenan memprediksi bahwa perusahaan dengan rasio leverage yang lebih tinggi akan mengungkapkan lebih banyak informasi, karena biaya keagenan perusahaan dengan struktur modal seperti itu lebih tinggi (Jensen dan Meckling, 1976 dalam Politon dan Rustiyaningsih, 2013).

Hasil uji statistik variabel growth $\left(\mathrm{X}_{3}\right) \mathrm{t}_{\text {hitung }}$ dan sig. hitung diperoleh angka 1,168 $<\mathrm{t}_{\text {tabel }} 1,654$ dan sig. hitung 0,245>0,05 ( $\alpha$ : 5\%) dengan demikian growth $\left(\mathrm{X}_{3}\right)$ tidak berpengaruh signifikan terhadap pengungkapan tanggung jawab sosial perusahaan $\left(\mathrm{Y}_{1}\right)$. Hasil penelitian ini sejalan dengan hasil penelitian yag dilakukan oleh Sari (2012). Investor lebih tertarik dengan kinerja keuangan perusahaan jangka pendek dengan berorientasi kepada keuntungan (profit) yang diperoleh pada tahun berjalan. CSR yang dilakukan perusahaan dianggap berpengaruh pada kinerja jangka menengah dan jangka panjang sehingga pertumbuhan perusahaan yang diukur dengan rasio pertumbuhan penjualan tidak mempengaruhi luas CSRD (Sari, 2012).

Hasil uji statistik variabel size $\left(\mathrm{X}_{4}\right) \mathrm{t}_{\text {hitung }}$ dan sig. hitung diperoleh angka 4,488 $>\mathrm{t}_{\text {tabel }} 1,654$ dan sig. hitung $0,000<0,05(\alpha: 5 \%)$ dengan demikian size $\left(\mathrm{X}_{4}\right)$ berpengaruh signifikan terhadap pengungkapan tanggung jawab sosial perusahaan $\left(\mathrm{Y}_{1}\right)$. Hasil penelitian ini tidak bertentangan dengan penelitian yang dilakukan oleh Sembiring (2005, Dewi dan Sitinjak (2009), Nurkhin (2010), Sari (2012), Dewi dan Keni (2013, dan Marhamah (2013). Perusahaan yang semakin besar memiliki asset yang banyak dan melakukan aktivitas yang banyak pula, hal ini akan menimbulkan interaksi baik secara langsung maupun tidak langsung dengan masyarakat, selain itu jumlah karyawan yang banyak juga akan menuntut perusahaan untuk menerapkan tanggung jawab sosialnya. Para shareholder menyadari hal ini dan menuntut pihak manajemen untuk melaporkannya dalam laporan tahunan sebagai sumber informasi bagi para stakeholder dan juga shareholder atas tanggung jawab sosial perusahaan.

Pengujian substruktural 2 di atas diketahui bahwa secara simultan profitabilitas, leverage, growth, size, dan pengungkapan tanggung jawab sosial perusahaan mempunyai pengaruh yang signifikan terhadap Harga Saham. Hal ini didasarkan pada perbandingan $F_{\text {hitung }}$ dengan $F_{\text {tabel }}$ dan signifikansi hitung berada di angka 0,05. Berdasarkan hasil pengujian statistik Uji Simultan (Uji F) $F_{\text {hitung }}$ diperoleh angka 20,160 > dari $\mathrm{F}_{\text {tabel }} 2,27$ dan sig. hitung 0,000<0,05 ( $\alpha$ : 5\%). Angka $\mathrm{R}$ Square yaitu 0,388 merupakan angka pengkuadratan dari koefisien korelasi atau $(0.623)^{2}=0,388$. R Square biasa disebut dengan koefisien determinasi, angka tersebut berarti $39 \%$ harga saham dapat dijelaskan oleh variabel profitabilitas, leverage, growth, size dan pengungkapan tanggung jawab sosial. Sedangkan sisanya $(100 \%-39 \%=$ $61 \%$ ) disebabkan oleh faktor-faktor lain. Faktor-raktor lain yang dimaksud antara lain adalah book value equity per share, likuiditas, efisiensi perusahaan, deviden, struktur aktiva dan struktur modal serta kemampuan manajemen untuk dapat memberikan informasi yang bernilai bagi investor dalam pengambilan keputusan untuk berinvestasi dan lain sebagainya.

Hasil uji statistik variabel profitabilitas $\left(\mathrm{X}_{1}\right) \mathrm{t}_{\text {hitung }}$ dan sig. hitung diperoleh angka 4,612 $>\mathrm{t}_{\text {tabel }}$ 1,654 dan sig. hitung $0,000<0,05(\alpha: 5 \%)$ dengan demikian profitabilitas $\left(\mathrm{X}_{1}\right)$ berpengaruh signifikan terhadap harga saham $\left(\mathrm{Y}_{2}\right)$. Hasil penelitian ini bertentangan dengan hasil penelitian Sinambela (2009), namun tidak bertentangan dengan Hasil penelitian Subiyantoro (2003, Pasaribu (2008), Deitiana (2011), 
Susilawati (2012), Mahapsari (2013), dan Wijaya dan Utama (2014). Melalui penelitian ini terbukti bahwa para investor masih mengutamakan kemampuan perusahaan dalam menghasilkan laba. Profitabilitas yang tinggi menunjukkan prospek usaha yang baik, hal ini memberi sinyal - sinyal positif bagi investor sehingga harga saham perusahaan meningkat.

Hasil uji statistik variabel leverage $\left(\mathrm{X}_{2}\right) \mathrm{t}_{\text {hitung }}$ dan sig. hitung diperoleh angka 3,217 $>\mathrm{t}_{\text {tabel }} 1,654$ dan sig. hitung $0,002<0,05(\alpha: 5 \%)$ dengan demikian leverage $\left(\mathrm{X}_{2}\right)$ berpengaruh signifikan terhadap harga saham $\left(\mathrm{Y}_{2}\right)$. Hasil penelitian ini sejalan dengan penilitian Pasaribu (2008) dan Susilawati (2012) namun berbeda dengan penelitian Sinambela (2009). Semakin tinggi leverage artinya modal sendiri semakin sedikit dibandingkan dengan hutang. Besarnya hutang perusahaan sebaiknya tidak boleh melebihi modal sendiri agar beban tetapnya tidak terlalu tinggi. Rasio ini juga dapat dibaca sebagai perbandingan antara dana pihak luar dengan dana pemilik perusahaan yang dimasukkan ke perusahaan.

Hasil uji statistik variabel growth $\left(\mathrm{X}_{3}\right) \mathrm{t}_{\text {hitung }}$ dan sig. hitung diperoleh angka $1,333<\mathrm{t}_{\text {tabel }} 1,654$ dan sig. hitung 0,184 >0,05 $(\alpha: 5 \%)$ dengan demikian growth $\left(\mathrm{X}_{3}\right)$ tidak berpengaruh signifikan terhadap harga saham $\left(\mathrm{Y}_{2}\right)$. Hasil penelitian ini sesuai dengan hasil penelitian yang dilakukan oleh Deitiana (2011), tetapi tidak sesuai dengan Pasaribu (2008), dan Wijaya dan Utama (2014). Growth yang diukur oleh pertumbuhan penjualan tidak selalu mencerminkan bahwa perusahaan tersebut bertumbuh dan semakin besar, karena pertumbuhan penjualan dapat juga dipengaruhi oleh kenaikan harga, promosi, dan sebagainya sehingga harga saham tidak dipengaruhi oleh growth yang ditunjukkan oleh pertumbuhan penjualan.

Hasil uji statistik variabel size $\left(\mathrm{X}_{4}\right) \mathrm{t}_{\text {hitung }}$ dan sig. hitung diperoleh angka 7,427 $>\mathrm{t}_{\text {tabel }}$ 1,654 dan sig. hitung $0,000<0,05(\alpha: 5 \%)$ dengan demikian size $\left(\mathrm{X}_{4}\right)$ berpengaruh signifikan terhadap harga saham $\left(\mathrm{Y}_{2}\right)$. Hasil penelitian ini berbeda dengan hasil penelitian yang dilakukan oleh Dewi dan Wirajaya (2013). Size merupakan salah satu indikator mengukur kinerja suatu perusahaan yang semakin berkembang. Size yang diukur dengan total aset perusahaan yang besar mencerminkan bahwa perusahaan mempunyai komitmen yang tinggi untuk terus tumbuh dan semakin besar, sehingga investor akan tertarik membeli saham perusahaan.

Hasil uji statistik variabel pengungkapan tanggung jawab sosial perusahaan $\left(\mathrm{Y}_{1}\right) \mathrm{t}_{\text {hitung }}$ dan sig. hitung diperoleh angka $0,750<\mathrm{t}_{\text {tabel }} 1,654$ dan sig. hitung 0,455 $>0,05(\alpha$ : $5 \%)$ dengan demikian pengungkapan tanggung jawab sosial perusahaan $\left(\mathrm{Y}_{1}\right)$ tidak berpengaruh signifikan terhadap harga saham $\left(\mathrm{Y}_{2}\right)$. Hasil penelitian ini bertolak belakang dengan hasil penelitian yang dilakukan oleh Marhamah (2013). Dari hasil penelitian ini dapat disimpulkan bahwa para investor masih menggunakan pertimbangan yang lain daripada pengungkapan tanggung jawab sosial sebagai indikator penilaian terhadap investasi yang akan dilakukan.

Koefisien pengaruh langsung profitabilitas $\left(\mathrm{X}_{1}\right)$ terhadap pengungkapan tanggung jawab sosial perusahaan $\left(\mathrm{Y}_{1}\right)$ adalah $\beta_{1}=0,102$. Koefisien pengaruh langsung pengungkapan tanggung jawab sosial perusahaan $\left(\mathrm{Y}_{1}\right)$ terhadap harga saham $\left(\mathrm{Y}_{2}\right)$ adalah $\beta_{9}=-0,050$. Koefisien pengaruh langsung profitabilitas $\left(\mathrm{X}_{1}\right)$ terhadap harga saham $\left(\mathrm{Y}_{2}\right)$ adalah $\beta_{5}=0,297$. Koefisien pengaruh tidak langsung profitabilitas $\left(\mathrm{X}_{1}\right)$ terhadap harga saham $\left(\mathrm{Y}_{2}\right)$ melalui pengungkapan tanggung jawab sosial perusahaan $\left(\mathrm{Y}_{1}\right)$ adalah $\beta_{10}=\beta_{1}$ $\mathrm{x} \beta_{9}=0,102 \mathrm{x}-0,050=-0,0051$. Dengan demikian koefisien pengaruh tidak langsung $\left(\beta_{10}=-0,0051\right)<$ koefisien pengaruh langsung $\left(\beta_{5}=0,297\right)$, artinya profitabilitas $\left(\mathrm{X}_{1}\right)$ tidak berpengaruh signifikan terhadap harga saham $\left(\mathrm{Y}_{2}\right)$ melalui pengungkapan tanggung jawab sosial perusahaan $\left(\mathrm{Y}_{1}\right)$.

Koefisien pengaruh langsung leverage $\left(\mathrm{X}_{2}\right)$ terhadap pengungkapan tanggung jawab sosial perusahaan $\left(\mathrm{Y}_{1}\right)$ adalah $\beta_{2}=0,229$. Koefisien pengaruh langsung pengungkapan tanggung jawab sosial perusahaan $\left(\mathrm{Y}_{1}\right)$ terhadap harga saham $\left(\mathrm{Y}_{2}\right)$ adalah $\beta_{9}=-0,050$. Koefisien pengaruh langsung leverage $\left(\mathrm{X}_{2}\right)$ terhadap harga saham $\left(\mathrm{Y}_{2}\right)$ adalah $\beta_{5}=-0,234$. Koefisien pengaruh tidak langsung leverage $\left(\mathrm{X}_{2}\right)$ terhadap harga saham $\left(\mathrm{Y}_{2}\right)$ melalui pengungkapan tanggung jawab sosial perusahaan $\left(\mathrm{Y}_{1}\right)$ adalah $\beta_{11}=\beta_{2}$ $\mathrm{x} \beta_{9}=0,229 \mathrm{x}-0,050=-0,01145$. Dengan demikian koefisien pengaruh tidak langsung $\left(\beta_{11}=-0,01145\right)>$ koefisien pengaruh langsung $\left(\beta_{6}=-0,234\right)$, artinya leverage $\left(\mathrm{X}_{2}\right)$ berpengaruh signifikan terhadap harga saham $\left(\mathrm{Y}_{2}\right)$ melalui pengungkapan tanggung jawab sosial perusahaan $\left(\mathrm{Y}_{1}\right)$.

Koefisien pengaruh langsung growth $\left(\mathrm{X}_{3}\right)$ terhadap pengungkapan tanggung jawab sosial perusahaan $\left(\mathrm{Y}_{1}\right)$ adalah $\beta_{3}=-0,085$. Koefisien pengaruh langsung pengungkapan tanggung jawab sosial perusahaan $\left(\mathrm{Y}_{1}\right)$ terhadap harga saham $\left(\mathrm{Y}_{2}\right)$ adalah $\beta_{9}=-0,050$. Koefisien pengaruh langsung growth $\left(\mathrm{X}_{3}\right)$ terhadap harga saham $\left(\mathrm{Y}_{2}\right)$ adalah $\beta_{7}=-0,083$. Koefisien pengaruh tidak langsung growth $\left(\mathrm{X}_{3}\right)$ terhadap harga saham $\left(\mathrm{Y}_{2}\right)$ melalui pengungkapan tanggung jawab sosial perusahaan $\left(\mathrm{Y}_{1}\right)$ adalah $\beta_{12}=\beta_{3} \times \beta_{9}=$ - 
$0,085 \times-0,050=0,00425$. Dengan demikian koefisien pengaruh tidak langsung $\left(\beta_{12}=0,00425\right)>$ koefisien pengaruh langsung $\left(\beta_{7}=-0,083\right)$, artinya growth $\left(\mathrm{X}_{3}\right)$ berpengaruh signifikan terhadap harga saham $\left(\mathrm{Y}_{2}\right)$ melalui pengungkapan tanggung jawab sosial perusahaan $\left(\mathrm{Y}_{1}\right)$.

Koefisien pengaruh langsung size $\left(\mathrm{X}_{4}\right)$ terhadap pengungkapan tanggung jawab sosial perusahaan $\left(\mathrm{Y}_{1}\right)$ adalah $\beta_{4}=0,384$. Koefisien pengaruh langsung pengungkapan tanggung jawab sosial perusahaan $\left(\mathrm{Y}_{1}\right)$ terhadap harga saham $\left(\mathrm{Y}_{2}\right)$ adalah $\beta_{9}=-0,050$. Koefisien pengaruh langsung size $\left(\mathrm{X}_{4}\right)$ terhadap harga saham $\left(\mathrm{Y}_{2}\right)$ adalah $\beta_{8}=0,572$. Koefisien pengaruh tidak langsung size $\left(\mathrm{X}_{4}\right)$ terhadap harga saham $\left(\mathrm{Y}_{2}\right)$ melalui pengungkapan tanggung jawab sosial perusahaan $\left(\mathrm{Y}_{1}\right)$ adalah $\beta_{13}=\beta_{4} \times \beta_{9}=0,384 \times-0,050=-$ 0,0192. Dengan demikian koefisien pengaruh tidak langsung $\left(\beta_{13}=-0,0192\right)<$ koefisien pengaruh langsung $\left(\beta_{8}=0,572\right)$, artinya size $\left(\mathrm{X}_{4}\right)$ tidak berpengaruh signifikan terhadap harga saham $\left(\mathrm{Y}_{2}\right)$ melalui pengungkapan tanggung jawab sosial perusahaan $\left(\mathrm{Y}_{1}\right)$.

\section{KESIMPULAN DAN SARAN \\ Kesimpulan}

Berdasarkan uji statistik yang telah dilakukan, hasil yang diperoleh adalah sebagai berikut :

1. Profitabilitas, leverage, growth, size dan pengungkapan tanggung jawab sosial perusahaan secara simultan mempunyai pengaruh yang signifikan terhadap harga saham perusahaan yang terdaftar di BEI.

2. Profitabilitas $\left(\mathrm{X}_{1}\right)$ tidak berpengaruh signifikan terhadap pengungkapan tanggung jawab sosial perusahaan $\left(\mathrm{Y}_{1}\right)$ dengan demikian $\mathrm{H}_{1}$ ditolak.

3. Leverage $\left(\mathrm{X}_{2}\right)$ berpengaruh signifikan terhadap pengungkapan tanggung jawab sosial perusahaan $\left(\mathrm{Y}_{1}\right)$ dengan demikian $\mathrm{H}_{2}$ diterima.

4. Growth $\left(\mathrm{X}_{3}\right)$ tidak berpengaruh signifikan terhadap pengungkapan tanggung jawab sosial perusahaan $\left(\mathrm{Y}_{1}\right)$ dengan demikian $\mathrm{H}_{3}$ ditolak.

5. Size $\left(\mathrm{X}_{4}\right)$ berpengaruh signifikan terhadap pengungkapan tanggung jawab sosial perusahaan $\left(\mathrm{Y}_{1}\right)$ dengan demikian $\mathrm{H}_{4}$ diterima.

6. Profitabilitas $\left(\mathrm{X}_{1}\right)$ berpengaruh signifikan terhadap harga saham $\left(\mathrm{Y}_{2}\right)$ dengan demikian $\mathrm{H}_{5}$ diterima.

7. Leverage $\left(\mathrm{X}_{2}\right)$ berpengaruh signifikan terhadap harga saham $\left(\mathrm{Y}_{2}\right)$ dengan demikian $\mathrm{H}_{6}$ diterima.

8. Growth $\left(\mathrm{X}_{3}\right)$ tidak berpengaruh signifikan terhadap harga saham $\left(\mathrm{Y}_{2}\right)$ dengan demikian $\mathrm{H}_{7}$ ditolak.

9. Size $\left(\mathrm{X}_{4}\right)$ berpengaruh signifikan terhadap harga saham $\left(\mathrm{Y}_{2}\right)$ dengan demikian $\mathrm{H}_{8}$ diterima.

10. Pengungkapan tanggung jawab sosial perusahaan $\left(Y_{1}\right)$ tidak berpengaruh signifikan terhadap harga saham $\left(\mathrm{Y}_{2}\right)$ dengan demikian $\mathrm{H}_{9}$ ditolak.

11. Profitabilitas $\left(\mathrm{X}_{1}\right)$ tidak berpengaruh signifikan terhadap harga saham $\left(\mathrm{Y}_{2}\right)$ melalui pengungkapan tanggung jawab sosial perusahaan $\left(\mathrm{Y}_{1}\right)$ dengan demikian $\mathrm{H}_{10}$ ditolak.

12. Leverage $\left(\mathrm{X}_{2}\right)$ berpengaruh signifikan terhadap harga saham $\left(\mathrm{Y}_{2}\right)$ melalui pengungkapan tanggung jawab sosial perusahaan $\left(\mathrm{Y}_{1}\right)$ dengan demikian $\mathrm{H}_{11}$ diterima.

13. Growth $\left(\mathrm{X}_{3}\right)$ berpengaruh signifikan terhadap harga saham $\left(\mathrm{Y}_{2}\right)$ melalui pengungkapan tanggung jawab sosial perusahaan ( $\left.\mathrm{Y}_{1}\right)$ dengan demikian $\mathrm{H}_{12}$ diterima.

14. Size $\left(\mathrm{X}_{4}\right)$ tidak berpengaruh signifikan terhadap harga saham $\left(\mathrm{Y}_{2}\right)$ melalui pengungkapan tanggung jawab sosial perusahaan $\left(\mathrm{Y}_{1}\right)$ dengan demikian $\mathrm{H}_{13}$ ditolak.

\section{Saran}

1. Bagi perusahaan, perlu memperhatikan profitabilitas, leverage, growth, size dan pengungkapan tanggung jawab sosial sebagai indikator yang secara bersama-sama atau simultan dapat mempengaruhi harga saham perusahaan yang terdaftar di BEI. Perusahaan juga hendaknya lebih peduli dalam hal pengungkapan tanggung jawab sosial perusahaan bukan hanya sebagai ketentuan perundang-undangan tapi juga sebagai salah satu kewajiban perusahaan yang harus dilaksanakan dan disampaikan kepada para stakeholder meskipun untuk saat ini tanggung jawab sosial perusahaan masih belum memberikan pengaruh positif yang signifikan bagi perusahaan. Para investor masih lebih menilai profitabilitas, leverage, dan size dalam pengambilan keputusan investasi.

2. Bagi investor, pengambilan keputusan yang baik dan tepat dalam hal berinvestasi untuk suatu perusahaan dalam bentuk saham perlu analisis yang baik dalam hal analisis fundamental. Para investor juga hendaknya dapat mendorong perusahaan untuk melakukan pengungkapan tanggung jawab sosialnya, untuk mendapatkan gambaran yang jelas mengenai kondisi perusahaan. 
3. Bagi penelitian selanjutnya, diharapkan untuk mengambil data terbaru yaitu tahun 2013 dan bisa menambahkan variabel rasio yang lain sebagai variabel independen ataupun intervening yang memberikan pengaruh lebih besar terhadap harga saham. Misalnya book value equity per share, likuiditas, efisiensi perusahaan, deviden, dan struktur modal serta kemampuan manajemen untuk dapat memberikan informasi yang bernilai bagi investor dalam pengambilan keputusan untuk berinvestasi dan lain sebagainya.

\section{DAFTAR PUSTAKA}

Agustine, Ira (2014). Pengaruh Corporate Social responsibility Terhadap Nilai Perusahaan. Jurnal Finesta, Vol. 2, No. 1.

Ali, Waris dan Rizwan (2013). Factors Influencing Corporate Social and Environmental Disclosure (CSED) Practices in The Developing Countries: An Institutional Theoritical Perspective. International Journal of Asian Social Science. Asian Economics And Social Society

Anugerah, Rita, dkk (2010). Pengaruh Ukuran Perusahaan, Leverage dan Profitabilitas Terhadap pengungkapan Tanggung Jawab Sosial Perusahaan Pada Perusahaan Manufaktur di BEI. Jurnal Ekonomi Universitas Riau, Pekanbaru.

Asnita, (2013). Pengaruh Kinerja keuangan Terhadap Harga Saham Pada Industri Farmasi di BEI Periode 2008-2010. Jurnal Dinamika Manajemen Vol 1 No 2. Universitas Jambi.

Barton, Carter et al. (1989). The First Amendment and the Fifth Estate, Regulation of Electronic Mass Media, Second Edition. New York: The Foundation Press Inc.

Bayoud, Marie dan Slaughter (2012). Factors Influencing Levels of Corporate Social Responsibility Disclosure by Libyan: A Mixed Study. International Journal of Economics and Finance Vol 4 No. 4. University of Southern Queensland (USQ), Australia.

Belkaoi, Ahmed dan Philip G. Karpik. (1989). Determinants of The Corporate Decision to Disclose Sosial Information. Accounting, Auditing and Accountability Journal 2.

Branco, Manuel C. dan Rodrigues, L. L. (2008). Factors Influencing Social Responsibility Disclosure by Portuguese Companies. Journal of Business Ethics (2008)

Christiawan, Rafika A. Putri (2014). Pengaruh Profitabilitas, Likuiditas, dan Leverage Terhadap Pengungkapan Corporate Social Responsibility (Studi Pada Perusahaan-perusahaan yang Mendapat Penghargaan ISRA dan Listed (Go-Public) di Bursa Efek Indonesia (BEI) 2010-2012). Business Accounting Review Vol 2 No 1. Universitas Kristen Petra.

Daniati, Ninna dan Suhairi (2006). Pengaruh Kandungan Informasi Komponen Laporan Arus Kas, Laba Kotor dan Size Perusahaan terhadap Expected Return Saham. Simposium Nasional Akuntansi IX

Darmadji, Tjiptono dan Hendi M. Fakhruddin (2001). Pasar Modal di Indonesia: Pendekatan Tanya Jawab, Edisi Pertama. Jakarta: Salemba Empat.

Deitiana, Tita (2011). Pengaruh Rasio Keuangan, Pertumbuhan Penjualan dan Deviden Terhadap Harga Saham. Jurnal Bisnis dan Akuntansi Vol 13 No 1. STIE Trisakti.

Deitiana, Tita (2013). Pengaruh Current Ratio, Return on Equity dan Total Asset Turn Over Terhadap Devidend Payout Ratio dan Implikasi pada Harga Saham Perusahaan LQ 45. Jurnal Bisnis dan Akuntansi Vol 15 No 1. STIE Trisakti.

Devie. (2003). Strategi Keuangan Matriks: Alat Bantu Keputusan Investasi dan Pembiayaan. Jurnal Akuntansi \& Keuangan. Vol 5 No. 1.

Echave, Jon dan Shyam S. Bhati (2010). Determinants of Social and Environmental Disclosure by Spanish Companies. GSMI Third Annual International Business Conference. Michigan, USA

Politon, Sontry O. dan Sri Rustiyaningsih. (2013). Karakteristik Perusahaan dan Pengungkapan Tanggung Jawab Sosial pada Perusahaan Manufaktur Go Publik. Jurnal Riset Manajemen dan Akuntansi Vol. 1 No. 1. Universitas Katolik Widya Mandala Madiun.

Elkington, J. (1997). Cannibals with Forks The Triple Bottom Line of 21st Century Business. Oxford: Captone Publishing Ltd.

Fama, Eugene F. (1978). "The Effect of a Firm Investment and Financing Decisison on the Welfare of its Security Holders". American Economic Review : Vol. 68 PP.271-282.

Ghozali, Imam dan A. Chariri (2007). Teori Akuntansi. Semarang : Badan Penerbit Undip. 
Haniffa, R.M. dan T.E. Cooke (2005). "The Impact of Culture and Governance on Corporate Social Reporting”. Journal of Accounting and Public Policy 24, pp. 391-430.

Harahap, (2007). Analisis Kritis Atas Laporan Keuangan, Edisi Pertama. Jakarta : Raja Grafindo Persada.

Ikatan Akuntan Indonesia (2015). Standar Akuntansi Keuangan. Jakarta : Salemba Empat.

Indrawati, Titik dan Suhendro (2006). Determinasi Capital Structure pada Perusahaan Manufaktur di Bursa Efek Jakarta Periode 2000-2004. Jurnal Akuntansi dan Keuangan Indonesia, Januari-Juni, Vol.3, No.1.

Januarti dan Nurul K. Wardani (2013). Pengaruh Karakteristik Perusahaan Terhadap Pengungkapan Corporate Social Responsibility (CSR) (Studi Empiris Pada Perusahaan manufaktur yang Terdaftar di Bursa Efek Indonesia tahun (2009 - 2011). Diponegoro Journal Of Accounting Vol 2, No. 2. Universitas Diponegoro, Semarang.

Keni dan Sofia Prima Dewi, (2013). Pengaruh Umur Perusahaan, Profitabilitas, Ukuran Perusahaan dan Leverage Terhadap Pengungkapan Tanggung jawab Sosial Perusahaan. Jurnal Bisnis dan Akuntansi Vol 15 No. 1. Universitas Tarumanegara.

Kennedy, dan Suzana, Anisa. A. (2013). Faktor - faktor yang Mempengaruhi Struktur Modal pada Perusahaan Real Estate and Property yang Go Public di Bursa Efek Indonesia. Jurnal Akuntansi.

Kholis, Nur (2013). Peran Kinerja Keuangan Terhadap Luas Pengungkapan Tanggung jawab Sosial Perusahaan (CSR). Graduasi Vol 29 Edisi Maret 2013.

Kuncoro, Mudrajat (2001). Metode Kuantitatif : Teori dan Aplikasi Untuk Bisnis dan Ekonomi. Yogyakarta : UPP-AMP YKPN.

Kusumajaya, Dewa Kadek Oka (2011). Pengaruh Struktur Modal dan Pertumbuhan Perusahaan Terhadap Profitabilitas dan Nilai Perusahaan pada Perusahaan Manufaktur di Bursa Efek Indonesia. Tesis Program Magister Manajemen Pascasarjana Universitas Udayana, Denpasar.

Kusumawati, Fariyana (2009). Pengaruh Risiko Bank dan Profitabilitas Terhadap Harga Pasar Saham Pada Perusahaan Perbankan. Jurnal Akuntansi, Manajemen Bisnis dan Sektor Publik, Vol. 6 No. 1, Universitas Trunojoyo.

Laily, Nurul (2013). Pengaruh Tangibility, Pertumbuhan Penjualan, Profitabilitas dan Ukuran Perusahaan terhadap Struktur Modal dan Harga Saham Perusahaan Pertambangan di Daftar Efek Syariah Tahun 2002 - 2010. Universitas Islam Negeri Sunan Kalijaga, Yogyakarta

Marhamah, (2013). Pengaruh Manajemen Laba, Ukuran Perusahaan Terhadap Corporate Social Responsibility (CSR) dan Nilai Perusahaan Pada Perusahaan manufaktur yang Tercatat di Bursa Efek Indonesia Tahun 2007-2010. Jurnal STIE Semarang Vol 5, No 3. STIE Semarang.

Munawir, (1979). Analisa Laporan Keuangan. Yogyakarta : Liberty.

Murni, Rachmawati dan Almar (2012). Pengaruh Pengungkapan Corporate Social Responsibility (CSR) Terhadap Profitabilitas Perusahaan. Seminar Nasional Akuntansi \& Bisnis 2012. Universitas Widyatama, Bandung.

Neveu, R. P. (1985). Fundamentals of Managerial Finance. 2nd Edition. Cincinnati : South Western Publishing Co.

Nurkhin, Ahmad (2010). Corporate Governance dan Profitabilitas, Pengaruhnya Terhadap Pengungkapan CSR Social Perusahaan. Jurnal Dinamika Akuntansi Vol 2 No 1. Universitas Negeri Semarang.

Nuraina, Elva (2012). Pengaruh Kepemilikan Institusional dan Ukuran Perusahaan Terhadap Kebijakan Hutang dan Nilai Perusahaan (Studi pada Perusahaan Manufaktur yang Terdaftar di BEI). Jurnal Bisnis dan Ekonomi Vol 19 No 2. IKIP PGRI Madiun.

Pasaribu, Rowland B. (2008). Pengaruh Variabel Fundamental Terhadap Harga Saham Perusahaan Go Public di BEI. Jurnal Ekonomi dan Bisnis Vol 2 No 2

Pranowo, Bambang (2009). Pengaruh Beberapa Kinerja Perusahaan Terhadap Harga Saham. Jurnal Ekonomi Bisnis Tahun 14 No. 3. Universitas Negeri Malang.

Purwanto, Agus (2011). Pengaruh Tipe Industri, Ukuran Perusahaan, Profitaabilitas, Terhadap Corporate Social Responsibility. Vol. 8 No. 1, November 2011: 1-94.

Raharjaputra, Hendra S. (2009). Manajemen Keuangan dan Akutansi Untuk Eksekutif Perusahaan. Jakarta : PT. Raja Grafindo Persada. 
Republik Indonesia (1995). Undang-undang Nomor 8 Tahun 1995 Tentang Pasar Modal. Lembaran Negara RI Tahun 1995, No. 64. Sekretariat Negara. Jakarta

Republik Indonesia (2007). Undang-undang Nomor 25 Tahun 2007 Tentang Penanaman Modal. Lembaran Negara RI Tahun 2007, No. 4724. Sekretariat Negara. Jakarta

Republik Indonesia (2007). Undang-undang Nomor 40 Tahun 2007 Tentang Perseroan Terbatas. Lembaran Negara RI Tahun 2007, No. 4756. Sekretariat Negara. Jakarta

Retno, Reni Dyah dan Denies Priantinah (2012). Pengaruh Good Corporate Governance dan Pengungkapan Corporate Social Responsibility terhadap Nilai perusahaan (Study Empiris Pada Perusahaan yang Terdaftar di Bursa Efek Indonesia Periode 2007 - 2010). Jurnal Nominal Vol. 1 No. 1. Fakultas Ekonomi Universitas Negeri Yogyakarta.

Riswari, Dyah Ardana (2012). Pengaruh Corporate Social Responsibility Tehadap Nilai Perusahaan Dengan Corporate Governance Sebagai Variabel Moderating (Studi pada Perusahaan Publik Non Finansial yang Tercatat di Bursa Efek Indonesia Tahun 2008-2009). Skripsi Fakultas Ekonomika dan Bisnis Universitas Dipenegoro. Semarang.

Rusli, En dan Meythi (2011). Pengaruh Likuiditas dan Profitabilitas Terhadap harga saham Perusahaan manufaktur yang Terdaftar di Bursa Efek Indonesia. Jurnal Bisnus manajemen dan Ekonomi Vol 10 No 2. Universitas Kristen Maranatha.

Sari, Rizkia Anggita (2012). Pengaruh Karakteristik Perusahaan Terhadap Corporate Social Responsibility Disclosure Pada Perusahaan Manufaktur yang Terdaftar di Bursa Efek Indonesia. Jurnal Nominal Vol 1 No. 1. Universitas Negeri Yogyakarta.

Sari, Juliarsa dan Rosiana (2013). Pengaruh Pengungkapan CSR Terhadap Nilai Perusahaan Dengan Profitabilitas Sebagai Variabel Pemoderasi. E-Jurnal Akuntansi. Universitas Udayana, Bali.

Sayekti, Yosefa dan Ludovicus Sensi Wondabio (2007). Pengaruh CSR Disclosure terhadap Earning Response Coefficient (Suatu Studi Empiris pada Perusahaan yang Terdaftar di Bursa Efek Jakarta). Simposium Nasional Akuntansi IX.

Sembiring, Eddy Rismanda (2003). Pengaruh Karakteristik Perusahaan Terhadap Pengungkapan Tanggungjawab Sosial: Study Empiris Pada Perusahaan yang Tercatat (Go-Public) di Bursa Efek Jakarta. Tesis. Pascasarjana Universitas Diponegoro, Semarang.

Sembiring, Eddy Rismanda (2005). Karakteristik Perusahaan dan Pengungkapan Tanggungjawab Sosial: Study Empiris pada Perusahaan yang Terdaftar di Bursa Efek Jakarta. SNA VIII, Solo.

Sinambela, Sarton (2009). Pengaruh Return on Assets (ROA), Return on Equity (ROE), Price Earning Ratio (PER), dan Debt to Equity Ratio (DER), Terhadap harga Saham Perusahaan. Majalah Forum Ilmiah Universitas Jakarta Vol 13 No 9.

Sitepu, Andre Christian dan Hasan Sakti Siregar. (2009). Faktor-Faktor yang Mempengaruhi Pengungkapan Informasi Sosial dalam Laporan Tahunan pada Perusahaan Manufaktur yang Terdaftar di Bursa Efek Jakarta. Jurnal Online. FE USU, Medan

Sitinjak dan Rosiyana Dewi (2009). Analisis Pengaruh Karakteristik Perusahaan Terhadap Earning Response Coefisient Dengan Corporate Social Responsibility Sebagai variabel Intervening Pada Perusahaan Manufaktur yang Terdaftar di Bursa Efek Indonesia. Jurnal Informasi, Perpajakan, Akuntansi dan Keuangan Publik Vol 4 No. 2. Universitas Trisakti, Jakarta.

Sriayu, Gusti Ayu Putu Wiwik dan Ni Putu Sri Harta Mimba (2013). Pengaruh Karakteristik Perusahaan Terhadap Corporate Social Responsibility Disclosure. E-Jurnal Akuntansi Universitas Udayana.

Subiyantoro, Edi dan Andreani Fransisca (2003). Analisis Faktor-faktor yang Memengaruhi Harga Saham (Kasus Perusahaan Jasa Perhotelan yang Terdaftar di Pasar Modal). Jurnal Manajemen dan Kewirausahaan, Vol. 5 No. 2. Universitas Kristen Petra.

Sugiyono, (2008). Metode Penelitian Kuantitatif, Kualitatif dan $R \&$ D. Bandung : Alfabeta.

Sujoko dan Ugy Soebiantoro. (2007). Pengaruh Struktur Kepemilikan Saham, Leverage, Faktor Interen dan Faktor Eksteren terhadap Nilai Perusahan. Jurnal Manajemen dan Kewirausahaan. Vol 9, No. 1.

Sunariyah, 2003. Pengantar Pengetahuan Pasar Modal, Edisi Ketiga, Yogyakarta : UPP-AMP YKPN.

Suripto, Bambang (1999). Pengaruh Karakteristik Perusahaan terhadap Luas Pengungkapan Sukarela dalam Laporan Keuangan Tahunan. Simposium Nasional Akuntansi II. 
Susilawati, Christine D. (2012). Analisis Perbandingan Pengaruh Likuiditas, Solvabilitas dan Profitabilitas terhadap Harga Saham pada Perusahaan LQ 45. Jurnal Akuntansi Vol 4 No. 2. Universitas Kristen Maranatha.

Suwahyono, Rajio dan Widi Hening Oetomo. (2003). Analisis Pengaruh Beberapa Variabel Fundamental Perusahaan Terhadap Harga Saham Perusahaan Telekomunikasi Yang Tercatat di Bursa Efek Jakarta. Jurnal Ekuitas. Vol.10 No.3.

Syarifuddin, Nur Afni (2008). Pengaruh Corporate Social Responsibility Disclosure,Timeliness, dan Debt to Equity Ratio Terhadap earning Response Coefficient (Studi Empiris Pada Perusahaan Manufaktur yang Terdaftar di Bursa Efek Indonesia). Jurnal Telaah dan Riset Akuntansi Vol 1 No. 1. Universitas Syiah Kuala.

Taman, Nunky R. Mahapsari (2013). Pengaruh Profitabilitas, Struktur Aktiva, dan Pertumbuhan Penjualan Terhadap Harga saham dengan Struktur Modal Sebagai variabel Intervening pada Perusahaan manufaktur di Bursa Efek Indonesia. Jurnal Nominal Vol 2 No 1. Universitas negeri Yogyakarta.

Udayani, Dewi dan I Gst. Ngr. Agung Suaryana (2013). Pengaruh Profitabilitas dan Investment Opportunity Set Pada Struktur Modal. E-Jurnal Akuntansi. Universitas Udayana, Bali

Utama dan Amelia Ramdhaningsih (2013). Pengaruh Indikator Good Corporate Governance dan Profitabilitas pada Pengungkapan Corporate Social Responsibility. E-Jurnal Akuntansi. Universitas Udayana, Bali.

Utama, I Putu Wijaya (2014). Pengaruh Profitabilitas, Struktur Aset, dan Pertumbuhan Penjualan Terhadap Struktur Modal Serta Harga Saham. E-Jurnal Akuntansi. Universitas Udayana, Bali.

Waryanti, (2009). Pengaruh Karakteristik Perusahaan terhadap Pengungkapan Sosial pada Perusahaan Manufaktur di Bursa Efek Indonesia. Skripsi S1 Akuntansi UNDIP.

Weston, J. F. dan Copeland T. E. (1989). Financial Management, 8th edition. Chicago : The Dryden Press.

Wirajaya dan Ayu S. Dewi (2013). Pengaruh Struktur Modal, Profitabilitas dan Ukuran Perusahaan pada Nilai Perusahaan. E-Jurnal Akuntansi. Universitas Udayana, Bali. 